\title{
Taxonomy and phylogenetic relationships of the coral genera Australomussa and Parascolymia (Scleractinia, Lobophylliidae)
}

\author{
Roberto Arrigoni1 ${ }^{1,7}$, Zoe T. Richards ${ }^{2}$, Chaolun Allen Chen ${ }^{3,4}$, Andrew H. Baird ${ }^{5}$, Francesca Benzoni ${ }^{1,6}$ \\ ${ }^{1}$ Dept. of Biotechnology and Biosciences, University of Milano-Bicocca, 20126, Milan, Italy \\ ${ }^{2}$ Aquatic Zoology, Western Australian Museum, 49 Kew Street, Welshpool, WA 6106, Australia \\ ${ }^{3}$ Biodiversity Research Centre, Academia Sinica, Nangang, Taipei 115, Taiwan \\ ${ }^{4}$ Institute of Oceanography, National Taiwan University, Taipei 106, Taiwan \\ ${ }^{5}$ ARC Centre of Excellence for Coral Reef Studies, James Cook University, Townsville, QLD 4811, Australia \\ ${ }^{6}$ Institut de Recherche pour le Développement, UMR227 Coreus2, 101 Promenade Roger Laroque, BP A5, 98848 \\ Noumea Cedex, New Caledonia \\ ${ }^{7}$ E-mail: roberto.arrigoni@unimib.it
}

Key words: COI, evolution, histone H3, Lobophyllia, Pacific Ocean, rDNA, Symphyllia, systematics, taxonomic revision

\begin{abstract}
Novel micromorphological characters in combination with molecular studies have led to an extensive revision of the taxonomy and systematics of scleractinian corals. In the present work, we investigate the macro- and micromorphology and the phylogenetic position of the genera Australomussa and Parascolymia, two monotypic genera ascribed to the family Lobophylliidae. The molecular phylogeny of both genera was addressed using three markers, the partial mitochondrial COI gene and the nuclear histone $\mathrm{H} 3$ and the ribosomal ITS region. Based on molecular data, Australomussa and Parascolymia belong to the Lobophylliidae and they cluster together with the genera Lobophyllia and Symphyllia within the same clade. While A. rowleyensis and $P$. vitiensis are closely related based on the three gene regions examined, their macro and micromorphology suggest that these species are distinct, differing in several characters, such as continuity and thickness of the costosepta, the number of septa, septal tooth height, spacing, and shape, and the distribution and shape of granules. Thus, we revise the taxonomic status of the genus Australomussa as a junior synonym of Parascolymia.
\end{abstract}

\section{Contents}

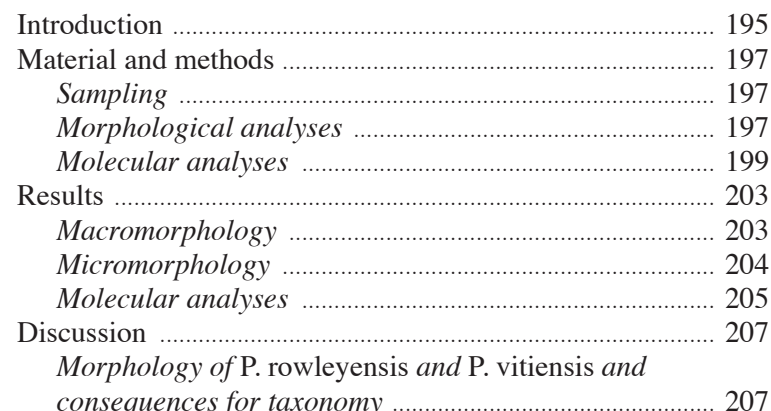

Molecular phylogeny of P. rowleyensis and P. vitiensis . 209

Utility of the examined molecular markers ...................... 209 Acknowledgements .............................................................. 210

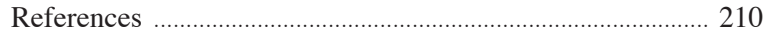

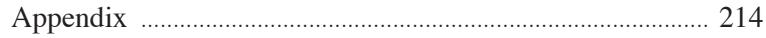

\section{Introduction}

Over the last two decades, our understanding of the evolution and the systematics of hard corals (Cnidaria, Anthozoa, Scleractinia) has rapidly advanced due to the progressive increase of molecular studies (Romano and Palumbi, 1996; Chen et al., 2002; Fukami et al., 2004, 2008; Kitahara et al., 2010; Stolarski et al., 2011). The new molecular phylogenies are, however, often very different from phylogenies based on macro-morphology (Fukami et al., 2004, 2008; Budd and Stolarski, 2009, 2011; Huang et al., 2011). Several recent papers integrating molecular and morphological approaches have led to formal taxonomic revisions of scleractinian corals at different taxonomic ranks (e.g. Wallace et al., 2007; Gittenberger et al., 2011; Kitahara et al., 2012, 2013; Benzoni et al., 2012a, 2014; Hoeksema, 2014; Kitano et al., 2014; Huang et al., 2014a, b). This integrated approach has proved effective at resolving longstanding issues, for example a comprehensive revision of the taxonomy and systematics of 23 nominal species of Psammocora Dana, 1846 (Stefani et al., 2008; Benzoni, 2006; Benzoni et al., 2010, 2012b) and 21 nominal species of Pocillopora Lamarck, 1816 (SchmidtRoach et al., 2012, 2013, 2014). 
The stony coral family Lobophylliidae Dai and Horng, 2009 has recently been studied by several authors using an integrated morpho-molecular approach, and is undergoing several taxonomic changes, although this process is far from complete. For example, Indo-Pacific taxa traditionally ascribed to the Mussidae Ortmann, 1890 have been moved to the Lobophylliidae as a result of the molecular work by Fukami et al. (2004, 2008), and the finding of a deep divergence between Indo-Pacific and Atlantic species based on morphological characters (Budd and Stolarski, 2009; Budd et al., 2012). The family Lobophylliidae is now comprised of the genera Lobophyllia de Blainville, 1830, Acanthastrea Milne Edwards and Haime, 1848, Cynarina Brüggemann, 1877, Echinophyllia Klunzinger, 1879, Homophyllia Brüggemann, 1877, Micromussa Veron, 2000, Moseleya Quelch, 1884, Oxypora Saville Kent, 1871, Parascolymia Wells, 1964 and Symphyllia Milne Edwards and Haime, 1848 (Budd et al., 2012). Also included in the family are two genera that have not been examined at a molecular level, namely Echinomorpha Veron, 2000 and Australomussa Veron, 1985, hence their phylogenetic placement is unresolved.

The macromorphology (budding, colony form, size and shape of corallites, numbers of septal cycles), the micromorphology (shapes and distributions of septal teeth and granules), and the microstructure (arrangement of calcification centres and thickening deposits within costosepta) of the lobophylliid genera Acanthastrea, Cynarina, Echinophyllia, Homophyllia, Lobophyllia, Micromussa, Oxypora, Parascolymia, and Symphyllia were examined by Budd and Stolarski (2009) and Budd et al. (2012). They concluded that the shape and distribution of septal teeth and granules, the area between teeth, and the development of thickening deposits are informative characters for distinguishing the Lobophylliidae from representatives of the other coral families. Arrigoni et al. (2014) presented a comprehensive molecular phylogeny that shows that the Lobophylliidae is a monophyletic family comprising nine main molecular clades (clades A-I), and that several genera are not monophyletic. The authors also showed that the monospecific genus Parascolymia belongs to clade I (sensu Arrigoni et al., 2014) together with all the species of Lobophyllia and Symphyllia for which molecular data is available, including the two type species $L O$ bophyllia corymbosa (Forskål, 1775) and Symphyllia radians Milne Edwards and Haime, 1849. The authors did not, however, undertake any formal taxo- nomic revision of the status of the genus Parascolymia.

Australomussa rowleyensis Veron, 1985 was described from Western Australia and ascribed to the Mussidae. It is a colonial and zooxanthellate scleractinian coral, characterized by flattened, helmet- or dome-shaped coralla, valleys approximately $20 \mathrm{~mm}$ wide, with very thick walls and a well-developed columella (Veron, 1985). In the original description of A.rowleyensis, Veron (1985) stated that this genus showed 'little resemblances to any other genus' with the exception of Parascolymia and Symphyllia, and 'its closest affinities are probably with the former'. The author referred only to the macromorphology of the coralla for the comparison of Australomussa with Parascolymia and Symphyllia and did not consider any micromorphological characters. Budd and Stolarski (2009) and Budd et al. (2012) showed that the majority of macromorphological characters traditionally used in the taxonomy and systematics of Lobophylliidae and Mussidae exhibit homoplasy. In contrast, novel micromorphological characters separate these two families and are useful for the description and formalization of species. Nevertheless, while the micromorphology of $P$. vitiensis (Brüggemann, 1877) was described by Budd and Stolarski (2009) and Budd et al. (2012), A. rowleyensis was not analysed in these studies.

The known distribution of $A$. rowleyensis includes the Western Pacific region known as the Coral Triangle (for definition see Hoeksema, 2007; Veron et al., 2009) and partially overlaps with the distribution of $P$. vitiensis which is absent from Western Australia but extends to the west in the Indian Ocean and to the east in the central Pacific (Veron, 2000). Australomussa rowleyensis and $P$. vitiensis have very different histories of nomenclature. Perhaps due to its recent description and rarity (Veron, 1985), A. rowleyensis has always been described as A. rowleyensis despite its morphological similarity to Parascolymia and Symphyllia (Veron, 1985, 2000). Conversely, $P$. vitiensis has a long history of nomenclatural confusion. It was originally ascribed to Litophyllia Milne Edwards and Haime, 1857 (Gardiner, 1899; Crossland, 1952) and later described as Protolobophyllia japonica Yabe and Sugiyama, 1935. In agreement with Matthai (1928), Wells (1937) and Vaughan and Wells (1943) considered Scolymia Haime, 1852 and Protolobophyllia Yabe and Sugiyama, 1935 as junior synonyms of Lobophyllia, presuming that the solitary forms were juvenile monostomatous stages of this 
colonial genus. Based on differences in macromorphology, Wells (1964) separated the Atlantic species Scolymia lacera (Pallas, 1766) from the Indo-Pacific species Scolymia vitiensis and established the genus Parascolymia for the latter one because he verified that the holotype of Protolobophyllia japonica was a specimen of Cynarina lacrymalis (Milne Edwards and Haime, 1848). Subsequently, Veron and Pichon (1980) synonymised Parascolymia with Scolymia based on the fact that these two genera are almost entirely monocentric, questioning also the validity of the geographical separation. Finally, Budd et al. (2012) restored the distinction between Parascolymia (Indo-Pacific) and Scolymia (Atlantic) based on molecular and micromorphological analyses (Fukami et al., 2004, 2008; Budd and Stolarski, 2009).

Although $P$. vitiensis is generally monocentric, it can also form polystomatous coralla (Chevalier, 1975; Veron and Pichon, 1980: figs 416-417) (Figs 1B-D, 2F-I). The macro-morphologic observation of a large series of mono- to polystomatous specimens of $P$. vitiensis from Papua New Guinea and New Caledonia and the similarity of the larger specimens with A. rowleyensis prompted the detailed study of the morphological affinities and molecular relationship between these two species and the two monospecific genera they are currently ascribed to.

Here we selected three DNA regions, the barcoding region of cytochrome oxydase subunit I gene, the nuclear ribosomal ITS region, and the nuclear histone H3 for molecular analysis of these species. The former two molecular loci have been extensively used in phylogenetic studies of scleractinian corals (Fukami et al., 2008; Gittenberger et al., 2011; Huang et al., 2011; Benzoni et al., 2011, 2014) and, moreover, the most comprehensive phylogeny reconstruction of the Lobophylliidae to date is based on these two markers (Arrigoni et al., 2014). The latter locus was revealed to be informative for a broad-based phylogeny of the Merulinidae Verrill, 1865 (Huang et al., 2011,2014b), a family closely related to the Lobophylliidae (Fukami et al., 2008; Arrigoni et al., 2012). Several phylogenetic studies of scleractinian corals achieved a well-resolved phylogeny using a concatenated species-tree, combining mitochondrial and nuclear molecular markers (Huang et al., 2009, 2011; Souter, 2010; Gittenberger et al., 2011; Benzoni et al., 2012a; Richards et al., 2013; Arrigoni et al., 2014). This kind of approach is a powerful way to obtain a robust phylogeny, resolving all key nodes and yielding good resolution at species level.
In the present paper, the phylogenentic relationships of A.rowleyensis with the rest of the Lobophylliidae are explored for the first time on the basis of three molecular loci, the barcoding region of cytochrome oxydase subunit I gene, the nuclear histone $\mathrm{H} 3$, and the nuclear ribosomal ITS region. In addition, we examined the macromorphology and micromorphology of A.rowleyensis and compared it to $P$. vitiensis.

\section{Material and methods}

\section{Sampling}

Specimens of Parascolymia vitiensis for this study were sampled in New Caledonia, Papua New Guinea, and Eastern Australia, while samples of Australomussa rowleyensis were collected in the Kimberley, North-West Australia (S1). Coral specimens were photographed and collected while SCUBA diving from 2 to 35 meters depth. Digital images of living corals in the field were taken with a Canon Powershot G9 in an Ikelite underwater housing system in New Caledonia and Papua New Guinea (Figs 1 and S5), and with an Olympus XZ1 in a PT-050 underwater housing in Australia (Figs 1 and S5). Coral specimens were collected, tagged, and preserved in $95 \%$ ethanol for further molecular analysis. After the sampling of fixed tissues for DNA extraction, each corallum was immersed in sodium hypochlorite for 48 hours to remove all soft parts, rinsed in freshwater and dried for microscope observation. Specimens were identified at the species level based on skeletal morphology using a Leica M80 microscope following the descriptions and illustrations by Chevalier (1975), Veron and Pichon (1980), and Veron (1985).

\section{Morphological analyses}

Images of coral skeletons were taken with a Canon G5 digital camera and through a Leica M80 microscope equipped with a Leica IC80HD camera. For high resolution and deep field close ups of three-dimensional details of corallites and septa, a series of images of the same subject at different focus intervals were taken (approximately 10) and the images were fused using the Helicon Focus 5.3 software (Kozub et al., 2000-2012). To compare macromorphology and micromorphology of $P$. vitiensis and A. rowleyensis we used a subset of 21 characters from Budd et al. (2012) (Table 1). We 

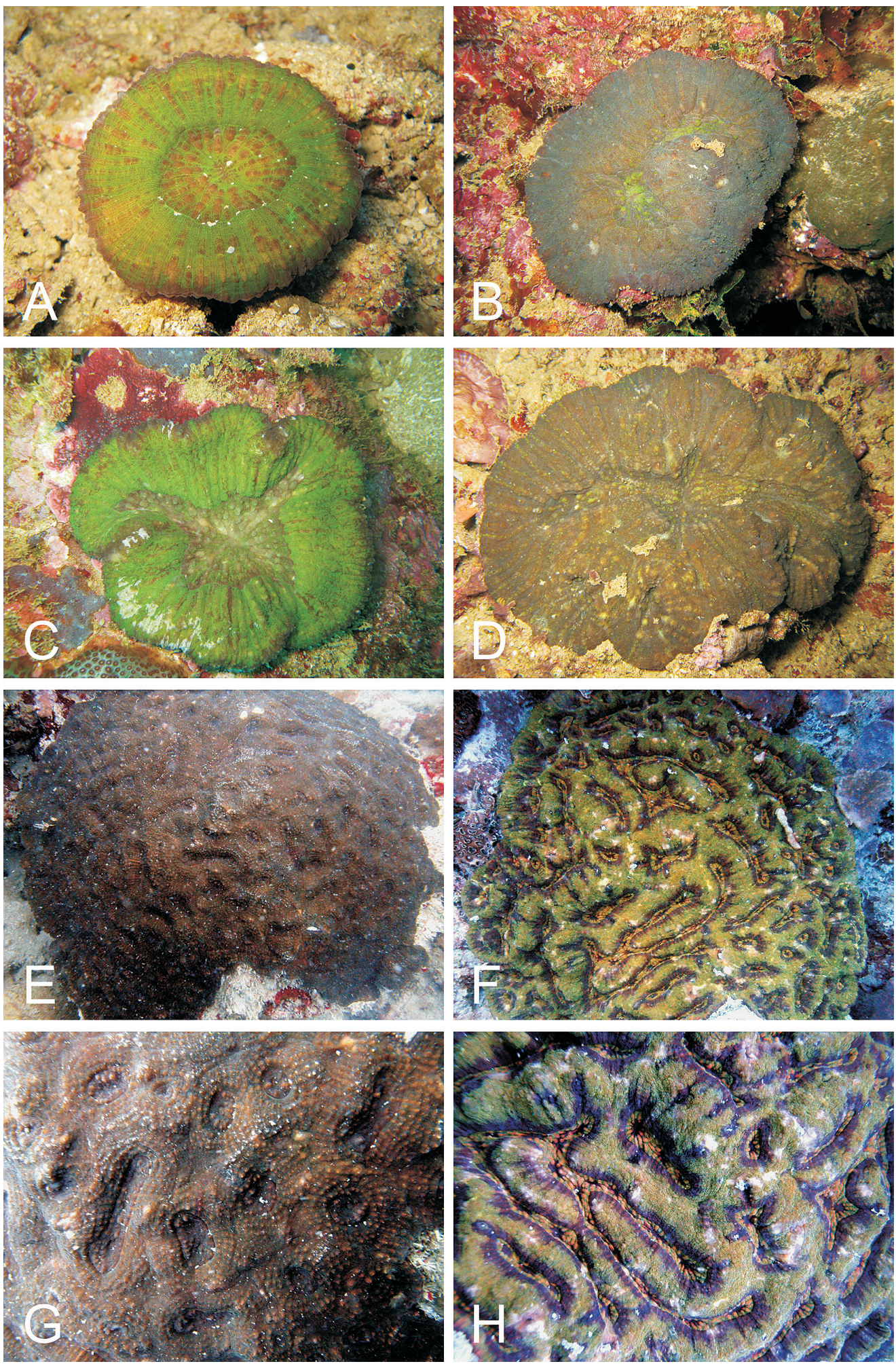

Fig. 1. Parascolymia vitiensis (A-D) and P. rowleyensis (previously Australomussa) (E-G) in situ: A) IRD HS2984 (monostomatous); B) UNIMIB PFB056 (bistomatous); C) IRD HS3139 (polystomatous, same as in Fig. 2H); D) UNIMIB PFB057 (polystomatous, same as in Fig. 2I); E) WAM Z65786; F) WAM Z65785; G) close up of the same colony as in E; H) close up of the same colony as in F. 
adopted their character name, ID number (in brackets) and state names and, when relevant quantitative differences between the two species were observed within a character state, this information was added after it. Given the large size of the skeletal structures in $P$. vitiensis and A. rowleyensis, the majority of macromorphological and micromorphological characters considered in this study, with the notable exception of characters 43 (granule shape and distribution) and 44 (interarea) from Budd et al. (2012), were examined using light microscopy. Scanning Electron Microscopy (SEM) was used to analyze the shape and distribution of granules on septal faces and the interarea of teeth on representative specimens of $P$. vitiensis (UNIMIB PFB151) and one of A. rowleyensis (WAM Z65789). Specimens were mounted using silver glue, sputter-coated with conductive gold film and examined using a Vega Tescan Scanning Electron Microscopy at the SEM Laboratory, University of Milano-Bicocca.

For a glossary of skeletal terms we refer to Budd $e t$ al. (2012).

Abbreviations:

CC1 IRD CoralCal1 Expedition, Côte Oubliée, New Caledonia, 2007

CC4 IRD CoralCal4 Expedition, New Caledonia, IRD, 2012

CCAP IRD CoralCap Expedition, New Caledonia, 2007

Cs cycle of costosepta

IRD Institut de Recherche pour le Développement, Nouméa, New Caledonia

NIUGINI Niugini Biodiversity Expedition, Papua

New Guinea, 2012

RMNH Naturalis Biodiversity Center (former

Rijksmuseum van Natuurlijke Historie),

Leiden, the Netherlands

$\mathrm{S} \quad$ cycle of septa

UNIMIB Università di Milano-Bicocca, Milan, Italy

WAM Western Australian Museum, Perth, Australia

In the list of examined material for IRD specimens the station number (ST) is provided, when available, after the sampling locality. Station numbers can be searched in the IRD online database LagPlon (http:// lagplon.ird.nc/consultv2_5/rechSimple.faces) where additional details on the reef habitat, GPS coordinates, and a map of each station can be found.

\section{Molecular analyses}

Whole genomic DNA was extracted from tissue samples using the DNeasy Blood and Tissue kit (Qiagen Inc., Valencia, CA, USA) according to the manufacturer's protocols. DNA concentration of extracts was quantified using a Nanodrop 1000 spectrophotometer (Thermo Scientific, Wilmington, DE, USA). A total of three molecular markers were amplified and sequenced for the majority of the specimens (S1): (1) a $\sim 750$ bp fragment of the cytochrome oxidase subunit I gene (COI) from mitochondrial DNA, (2) a 350 bp portion of the nuclear histone $\mathrm{H} 3$, and (3) a $\sim 800 \mathrm{pb}$ portion of the ITS region, including the 3' end of $18 \mathrm{~S}$, the entire ITS1, 5.8S, and ITS2, and the 5' end of the $28 \mathrm{~S}$, as nuclear loci. COI was amplified using MCOIF - MCOIR primers (Fukami et al., 2004) and the protocol by Benzoni et al. (2011), the histone $\mathrm{H} 3$ using H3F - H3R primers (Colgan et al., 1998), and the ITS region using ITS4 (Takabayashi et al., 1998) - A18S (White et al., 1990) primers and the protocol by Benzoni et al. (2011), or alternately using $1 \mathrm{~S}$ and 2SS primers (Wei et al., 2003) and the protocol by Kitano et al. (2014). Sequencing was carried out by Genomics and Bioscience and Technology Co., Ltd, Xizhi City, Taipei County, Taiwan. Sequences obtained in this study have been deposited in EMBL, and accession numbers are listed in $\mathrm{S} 1$.

Sequences were viewed, edited and assembled using CodonCode Aligner 4.2.5 (CodonCode Corporation, Dedham, MA, USA) and manually checked using BioEdit 7.2.5 (Hall, 1999). Alignments of the four separated datasets (three single gene trees and one concatenated) were carried out using the E-INS-i option in MAFFT 7.110 (Katoh et al., 2002; Katoh and Standley, 2013) under default parameters. Plesiastrea versipora (Lamarck, 1816) and several species from the family Merulinidae were selected as outgroups due their divergence from the family Lobophylliidae (Fukami et al., 2008; Kitahara et al., 2010; Benzoni et al., 2011). Indels, invariable, and parsimony informative sites were detected with DnaSP 5.10.01 (Librado and Rozas, 2009) and Indels were treated as a fifth character in phylogenetic analyses. Genetic distances and their standard deviation were calculated as $p$-distance with 500 bootstrap replicates using MEGA 5.2 (Tamura et al., 2011). To reconstruct the single gene trees Bayesian Inference (BI) and Maximum Likelihood (ML) analyses were used as implemented in MrBayes 3.1.2 (Ronquist and Huelsenbeck, 2003) and PhyML 3.0 (Guindon and 

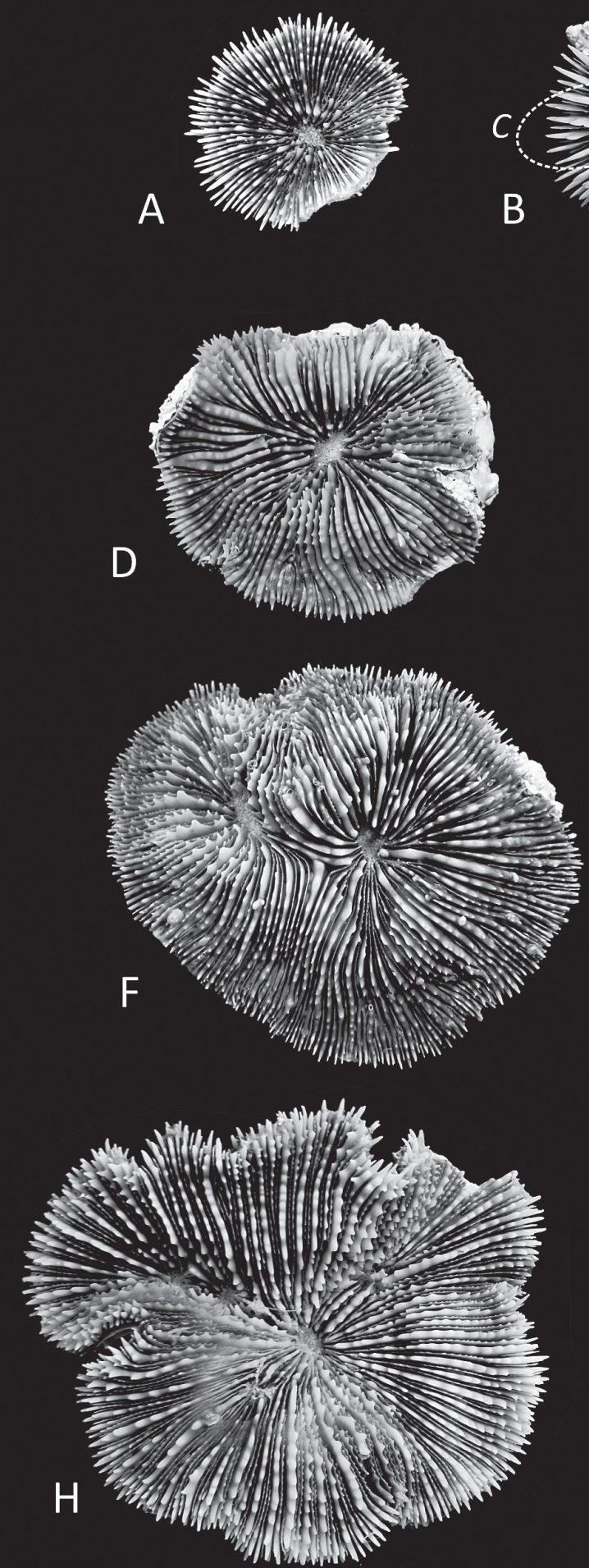
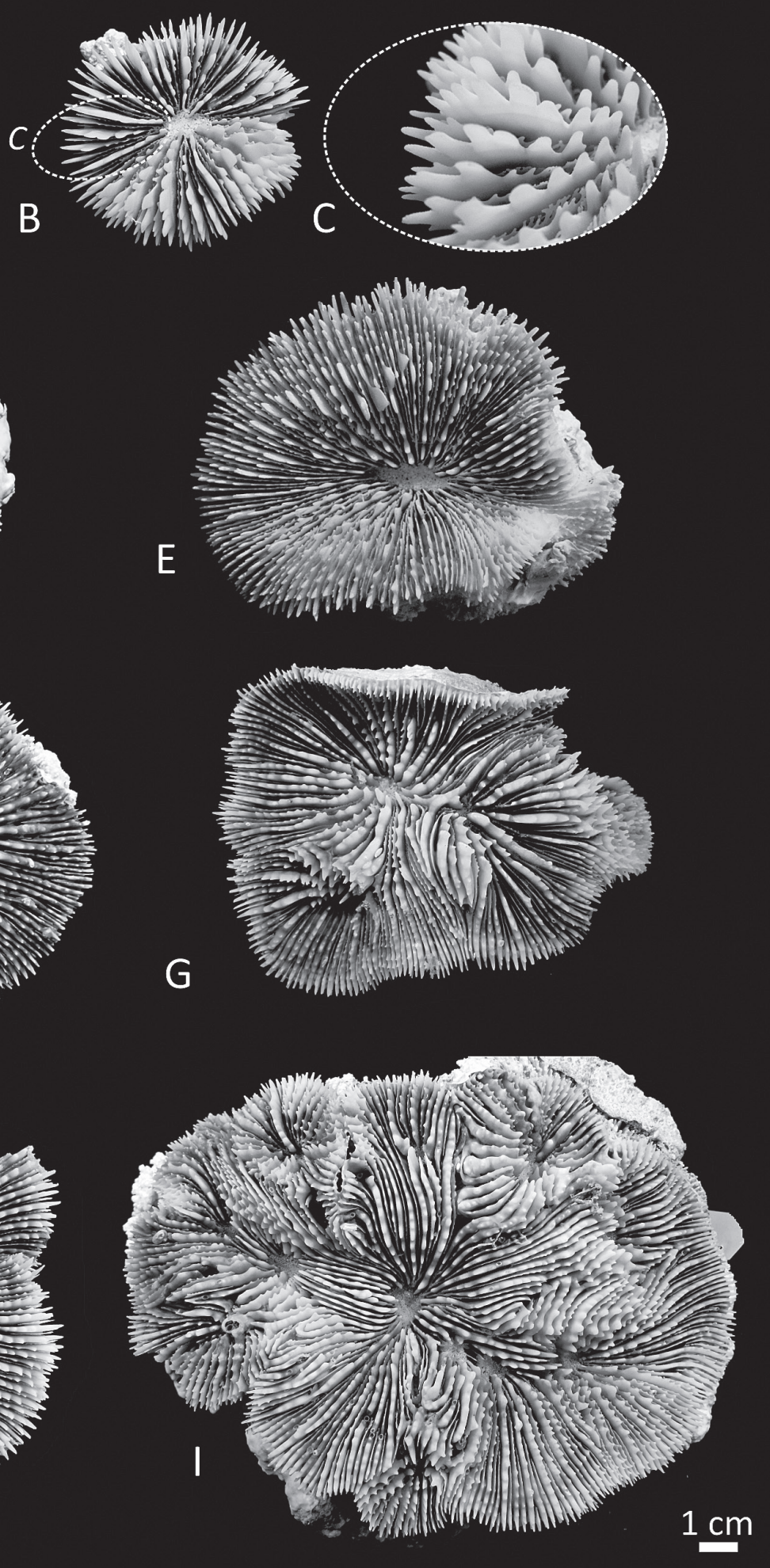

Fig. 2. Corallum morphology in Parascolymia vitiensis: A) IRD HS3255; B) IRD HS2955; C) detail of the same specimen in B showing variability in shape and size of septal teeth; D) UNIMIB PFB031; E) IRD HS2985; F) UNIMIB PFB056; G) UNIMIB PFB055; H) IRD HS3139; I) UNIMIB PFB057. All specimens are in the phylogenetic trees in Figs 9, S1-S3. 

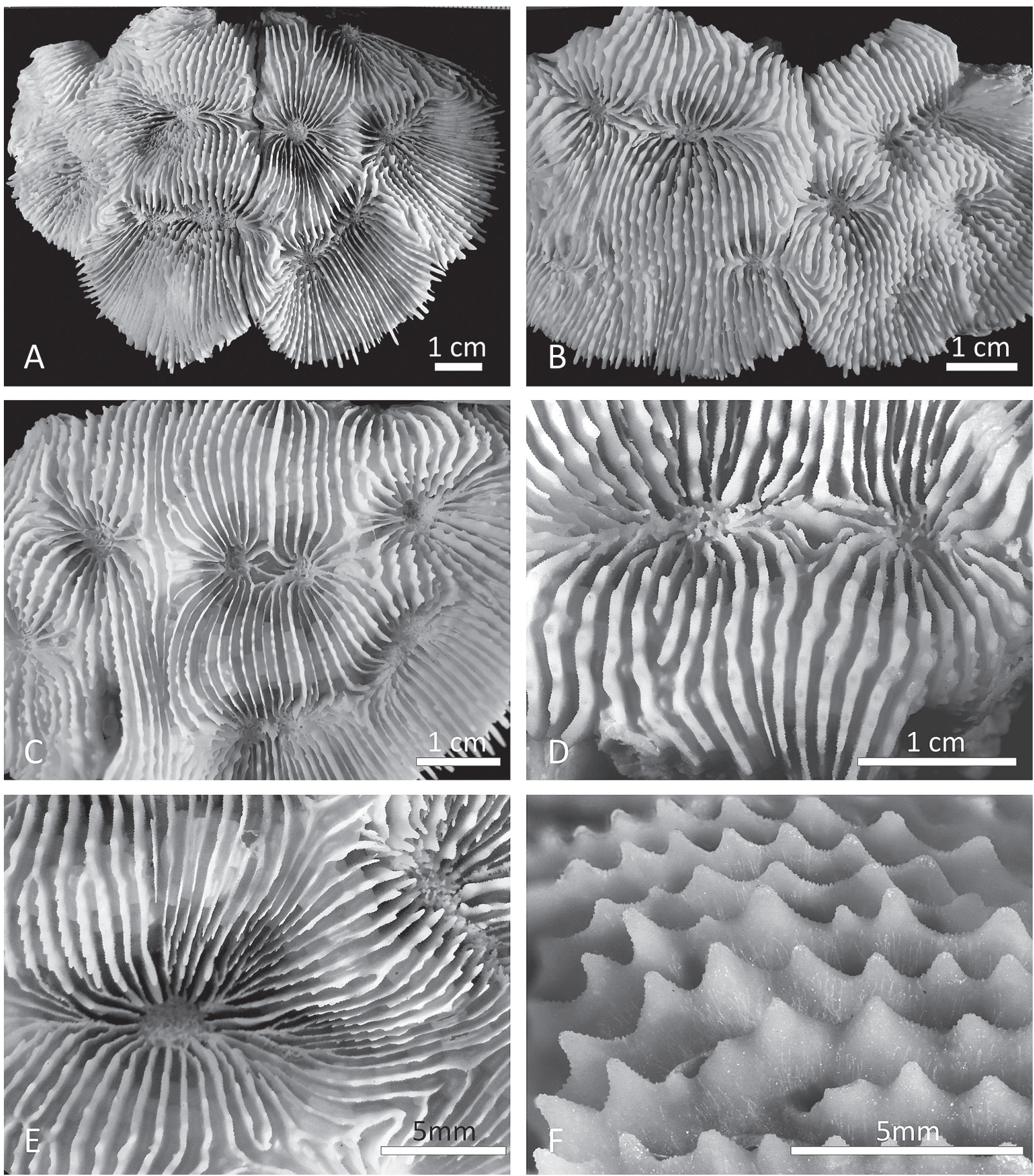

Fig. 3. Corallum morphology in Parascolymia rowleyensis (previously Australomussa): A) WAM Z65785; B) WAM Z65788; C) WAM Z65786; D) lamellar linkage between centres of adjacent corallites in same specimen as in B ; E) corallite polymorphism in the same specimen as in A; F) size and shape of costosepta in specimen WAM Z65787. All specimens are in the phylogenetic trees in Figs 9, S1-S3. 

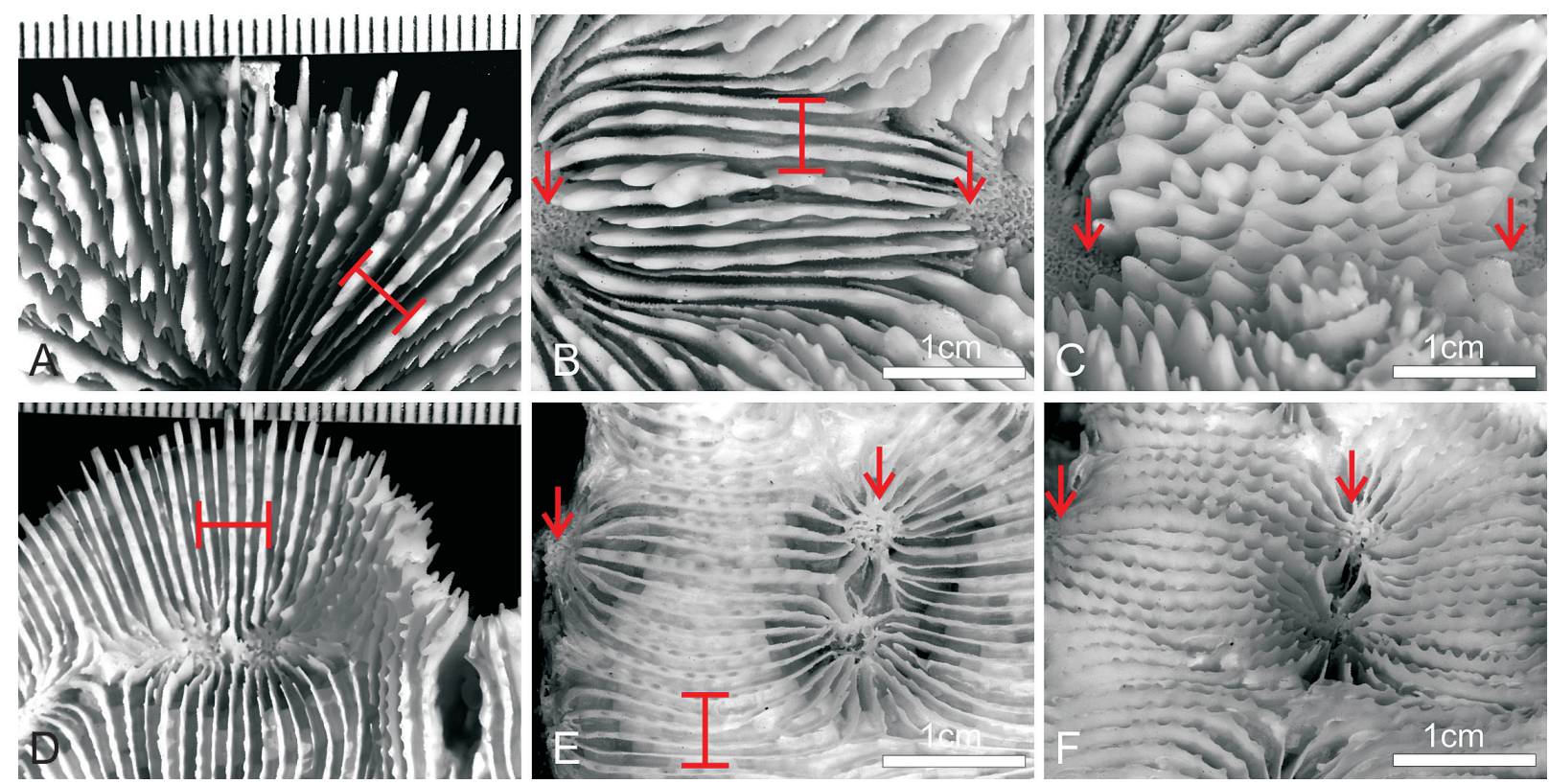

Fig. 4. Comparison of the macromorphology of Parascolymia vitiensis (A-C) and P. rowleyensis (D-E): A) septa in the monocentric specimen IRD HS2964; B) top view of the costosepta in the polycentric specimen UNIMIB PFB057; C) side view of the same portion of the specimen in B; D) peripheral calices in specimen WAM Z65786; E) top view of the costosepta in the same specimen as D; F) side view of the same portion of the specimen in E. Red arrows indicate the position of the columella in adjacent corallites, red brackets placed perpendicularly to the costosepta show the number of costosepta intercepted by a $1 \mathrm{~cm}$ transect.
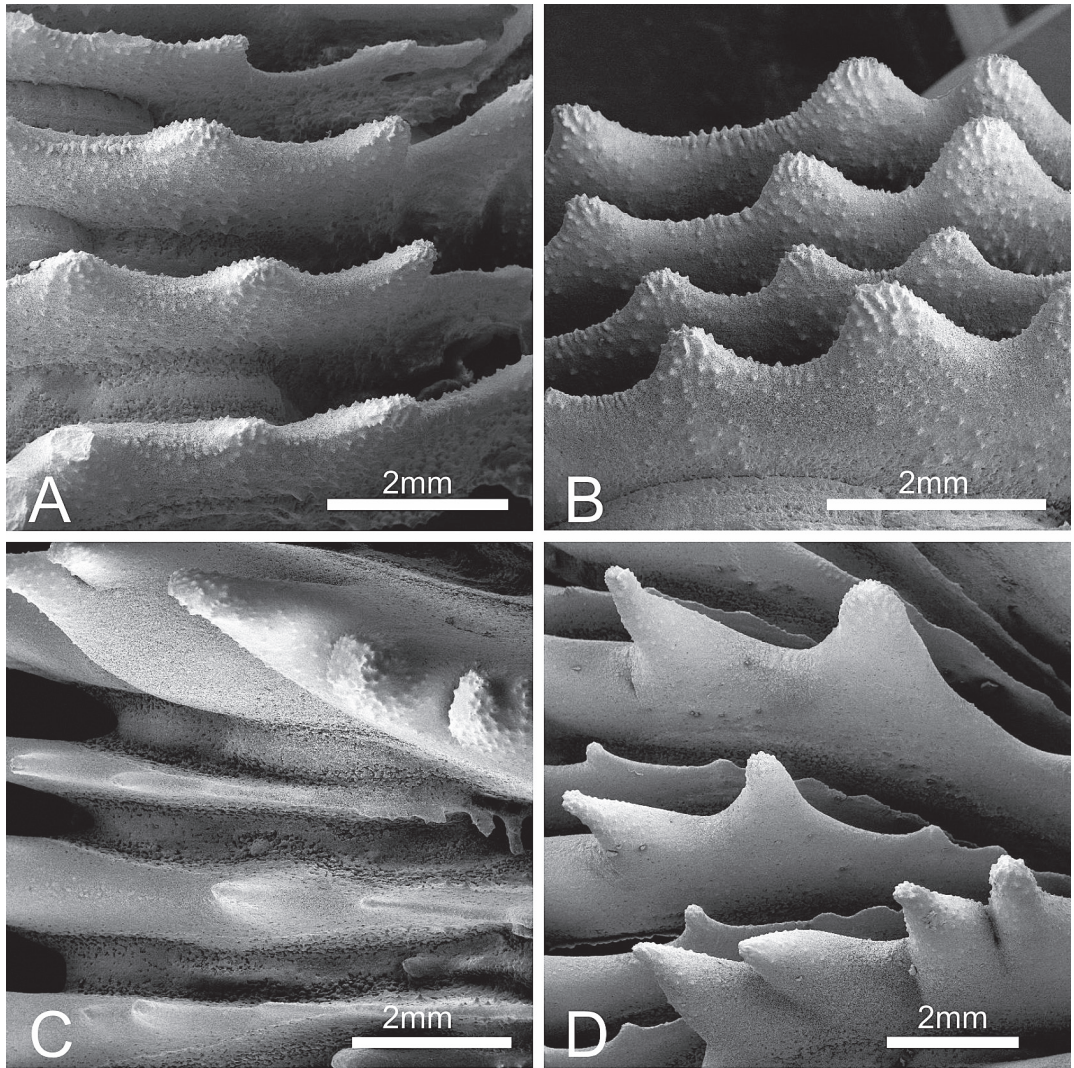

Fig. 5. SEM images of radial elements of Parascolymia rowleyensis (previously Australomussa) (WAM Z65789: A-B) and $P$. vitiensis (UNIMIB PFB151: C-D): A) top view of septa reaching the wall; B) side view of septa of different cycles showing some variability in septal teeth size between cycles but overall homogeneous shape; C) top view of septa reaching the wall; D) side view of septa of different cycles showing high variability in septal teeth size and shape between cycles. 

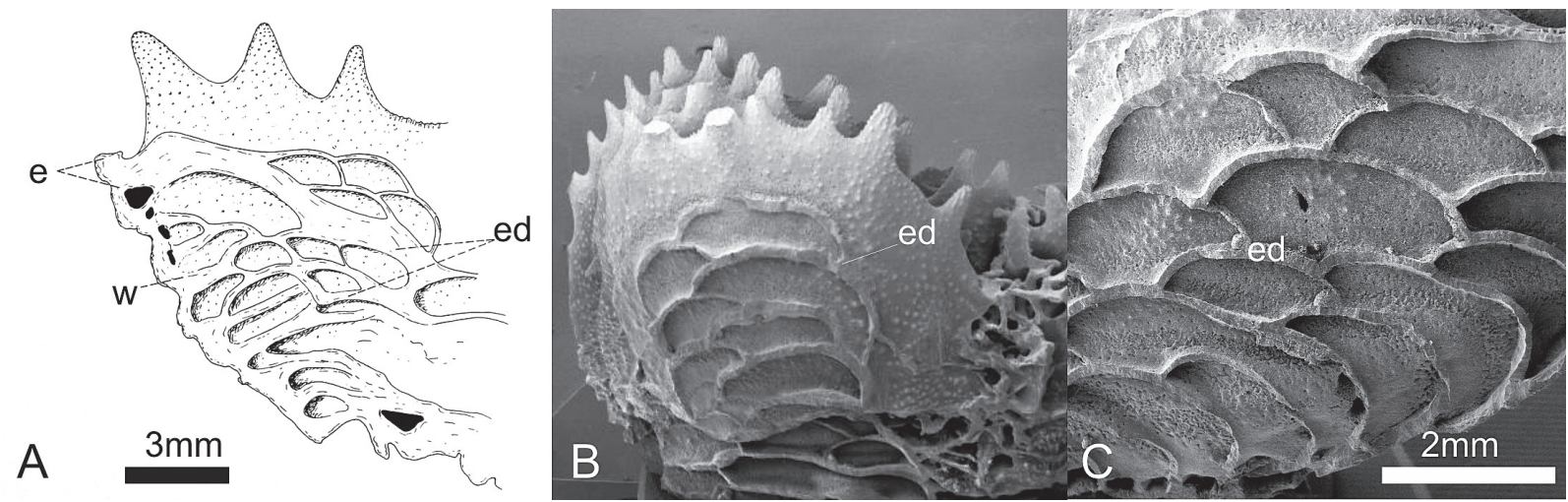

Fig. 6. Vesicular endotheca: A) longitudinal section of the periphery of a calice of Parascolymia vitiensis (modified from Chevalier, 1975: Fig. 190); B) SEM image of a longitudinal section along the septa of P. rowleyensis (WAM Z65789); C) detail of vesicular endothecal dissepiments in the same specimen as in B. e = epitheca; $w=$ wall; ed = endothecal dissepiments.

Gascuel, 2003), respectively. The best-fit substitution model for each locus was determined using the Akaike Information Criterion (AIC) as implemented in MrModeltest 2.3 (Nylander, 2004) in conjunction with PAUP4.0b10 (Swofford, 2003). As most suitable models AIC selected the General Time-Reversible (GTR) model with a proportion of sites being invariable $(+\mathrm{I})$ and the remainder following a gamma distribution $(+\mathrm{I})$ for COI and rDNA, and the Kimura (K80) model with a proportion of invariable sites (+I) for histone H3.

The Maximum Likelihood (ML) tree was calculated with PhyML and a total of 500 bootstrap replicates were performed to assess the robustness of each clade. Four independent Markov Chain Monte Carlo (MCMC) runs were conducted for $1.4 \times 10^{7}$ generations for COI dataset $\left(1.7 \times 10^{7}\right.$ generations for histone $\mathrm{H} 3$ and $4 \times 10^{7}$ generations for ITS region) with trees sampled every 100 generation for each analysis. The $25 \%$ first trees were discarded as burn-in, and posterior probabilities were estimated from the remaining trees in each run $(10,500$ remaining trees for COI, 12,750 for histone $\mathrm{H} 3$, and 30,000 for ITS region). To determine if the runs had achieved stationarity, we visualized log-likelihood scores and model parameter values across each run using Tracer 1.5 (Rambaut and Drummond, 2007). Finally, the three single gene datasets were concatenated in a single partitioned alignment and the phylogeny was reconstructed using Bayesian Inference and Maximum Likelihood analyses. Four independent Markov Chain Monte Carlo (MCMC) runs were conducted for $2.2 \times 10^{7}$ generations with trees sampled every 100 generation and the $25 \%$ first trees were discarded as burn-in. The ML tree was built in PhyML and a total of 500 bootstrap replicates were performed to assess the robustness of each clade. Branches with $>70 \%$ bootstrap support values and $>0.90$ posterior probabilities are considered significantly supported.

\section{Results}

\section{Macromorphology}

In $P$. vitiensis coralla can be solitary (Figs 1A, 2A-E) or colonial (Figs 1B-D, 2F-I) and formed by intracalicular and extracalicular budding (e. g. Fig. 2I). In colonial coralla, as a result of circumoral budding, corallites are highly polymorphic (Fig. 2G-I) and corallite integration is uni- or multiserial. Corallum shape is generally flattened or concave (Figs 1-2). Calice or valley width is larger than $2.5 \mathrm{~cm}$ (Fig. 2) and variable. In some specimens the central part of the calice can have a shallow depression (Fig. 2D-F, H). Continuity of costosepta is mostly confluent in di-tricentric coralla (Fig. 2F-G), but becomes mostly not confluent in polycentric coralla (Fig. 2I; Veron and Pichon, 1980: Fig. 417). There are six cycles of septa in the calices, rarely seven (Fig. 2E; Chevalier, 1975), those of the sixth are free. Septa spacing is large, with 4-5 septa per $5 \mathrm{~mm}$ (Fig. 4A-B). Relative costosepta thickness between Cs1 and Cs2 versus Cs3 is unequal (Fig. 5C-D). In polycentric coralla linkage between centres of adjacent corallites within series is lamellar (Fig. 4B-C). Columella trabecular and spongy (indicated by arrows in Fig. 4B-C) and its size relative to calice width is less 

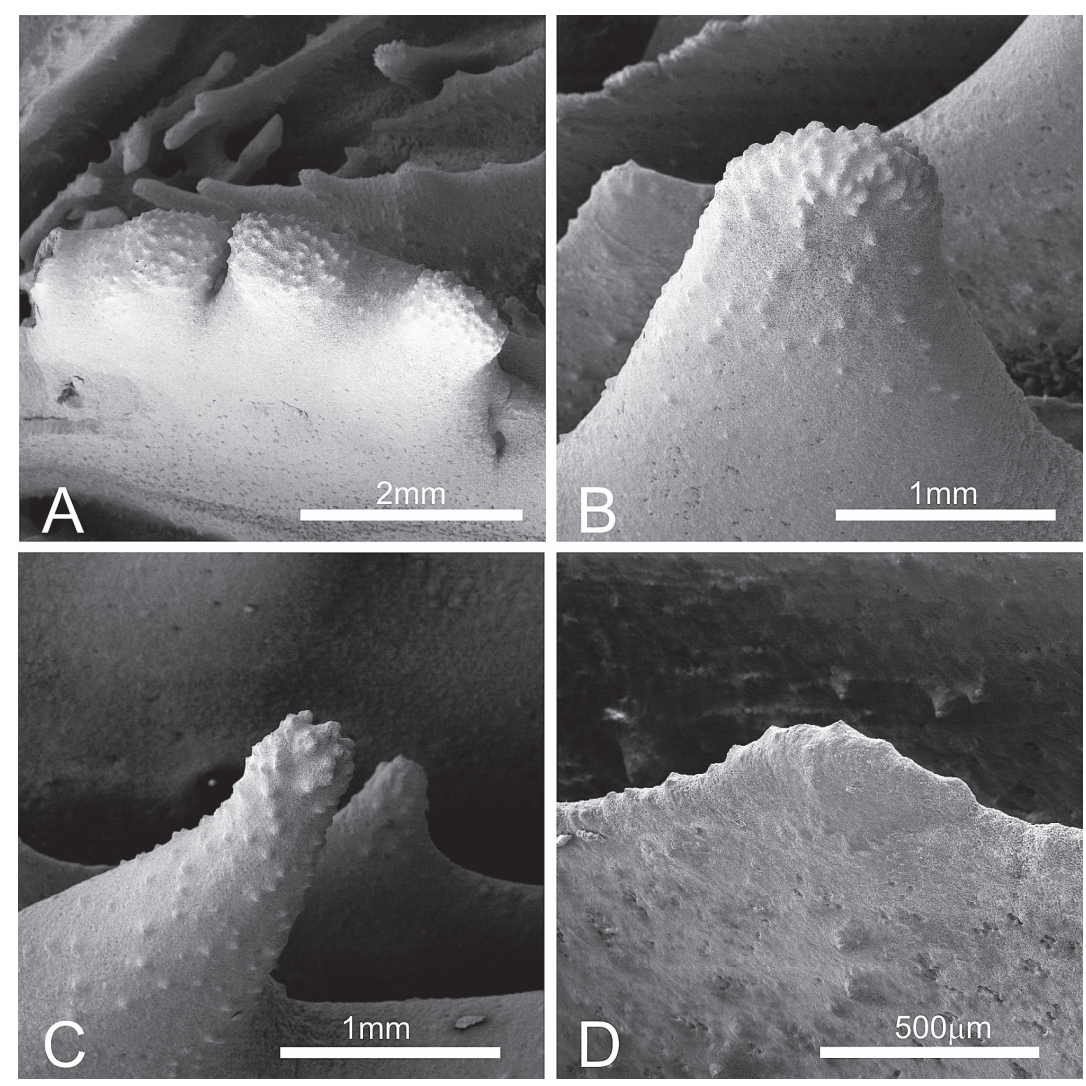

Fig. 7. SEM of Parascolymia vitiensis (UNIMIB PFB151): A) top view of a S1 showing its thickness and clumped teeth; B) side view of an S2 septum tooth; C) side view of an $\mathrm{S} 2$ septum tooth, note the difference in shape of the tooth tip compared to B; D) side view of an S5 septum tooth. than 1/5 (Fig. 2). The endotheca is vesicular (Fig. $6 \mathrm{~A})$.

In A. rowleyensis coralla are flattened or massive and 'helmet- or dome-shaped' (Fig. 1E-H). Coralla are colonial as a result of primary circumoral budding and both intra and extracalicular budding occur (Fig. 3D-E). Corallites display polymorphism in smaller colonies where the central corallite is still larger as in the paratype WAM 173-84 (Veron, 1985: Fig. 25) and corallite integration is uni- or multiserial. Calice or valley width is large according to the character state in Budd et al. (2012) but smaller than $2.5 \mathrm{~cm}$ (Fig. $4 \mathrm{D}-\mathrm{F})$. Calices at the periphery of the coralla can be inclined and the part of their calice which is not adjacent to other calices can be wide (Fig. 3A-B, 6D). Continuity of costosepta is mostly confluent (Fig. 3A-E, 4E-F). There are four cycles of septa (Fig. 3D), those of the fourth are free. Septa spacing is large, with five septa per 5mm (Fig. 4D-E). Relative costosepta thickness between Cs 1 and Cs 2 versus $\mathrm{Cs} 3$ is slightly unequal (Fig. 5A-B). Linkage between centres of adjacent corallites within a series is lamellar (Fig. 4D-F). Columella are trabecular and spongy (in- dicated by arrows in Fig. 4E-F) and the size relative to calice width less than or equal to $1 / 4$ of calice width (Figs 3D-E, 4D-F). The endotheca is vesicular (Fig. 6B-C).

\section{Micromorphology}

In $P$. vitiensis tooth base at mid-septum is elliptical in shape and parallel to the direction of the septum (Fig. 5C-D). Tooth tips are irregular and overall mainly lobate (Figs 5D, 7A-B, D). Teeth on $\mathrm{S} 1$ are $1 \mathrm{~mm}$ or higher (Figs 4C, 7) and their spacing is very wide, with adjacent teeth more than $2 \mathrm{~mm}$ apart. Tooth shape and size is very variable within and between septa (Fig. 7) as also noted by previous authors (Chevalier, 1975; Veron and Pichon, 1980) with some teeth becoming round in section towards the tip and having and overall pointed, or spiniform Chevalier (1975), shape (Fig. 7C). Granulation on the side of septa is weak and granules are enveloped by thickening deposits (Fig. 7A-B). The inter-area structure is generally smooth (Fig. 5D) or with palisade. Tooth shape between Cs3 and Cs1 is unequal (Fig. 5C-D). 

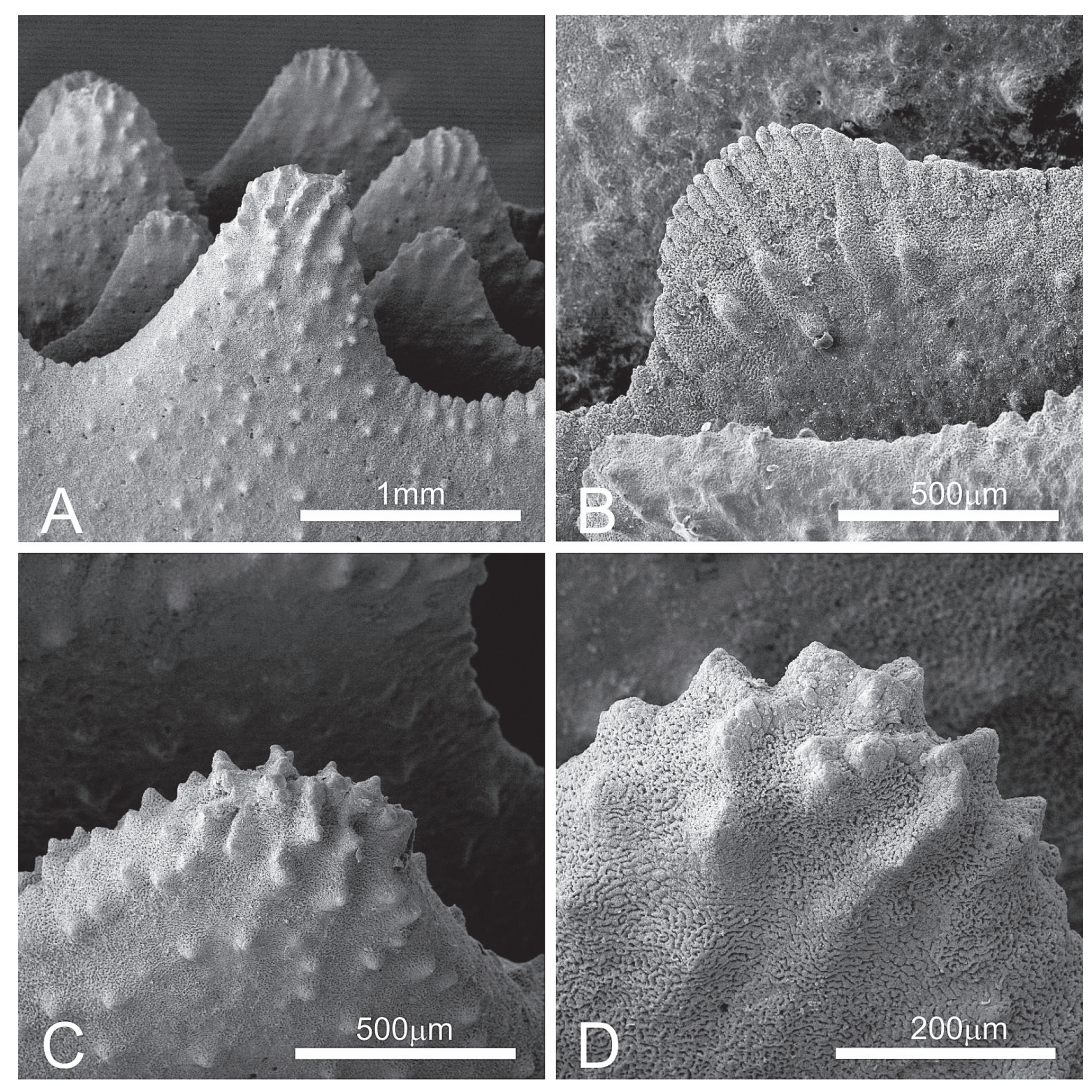

Fig. 8. SEM of Parascolymia rowleyensis (previously Australomussa) (WAM Z65789): A) side view of septa of different cycles showing homogeneous shape of septum teeth between cycles; B) side view of an S4 septum tooth; C) side view of an S2 septum tooth showing granulation; D) side view of the tip of an S1 septum tooth.
In A. rowleyensis tooth base at mid-septum is elliptical in shape and parallel to the direction of the septum (Fig. 5A-B). Tooth tips are irregular and lobate (Figs 5B, 8). Teeth on S1 range between 0.8-0.9 $\mathrm{mm}$ (Figs 4F, 8) and their spacing is wide, with adjacent teeth between 1 and $2 \mathrm{~mm}$ apart. Granulation on the side of septa is strong and granules are scattered (Figs 5B, 8A). The inter-area structure has a palisade structure (Fig. 8A). Tooth shape between Cs3 and Cs1 is equal (Fig. 5B). In general, in this species tooth shape is not very variable within and between septa (Fig. 5A-B) especially when compared to the variability described in $P$. vitiensis.

\section{Molecular analyses}

The final alignment of COI data consisted of $580 \mathrm{bp}$, of which 48 were parsimony informative sites, with a total of 84 mutations. The aligned histone H3 matrix was 318 bp long with 86 parsimony informative sites and 122 mutations. The total alignment of ITS region was composed by $951 \mathrm{bp}, 160$ parsimony informative sites and 294 mutations. No intra-individual poly- morphisms or double peaks were observed in the chromatograms of the two nuclear loci, thereby avoiding the need to clone the amplified fragments. The phylogeny reconstruction of the combined molecular data is in Fig. 9, while the three single gene trees are in the Supplementary Information (Figs S2S4). Phylogenetic analyses under BI and ML criteria yielded congruent results, with no contrasting signals. Bayesian topologies with significant branch support indicated by ML bootstrapping support (MLs) and Bayesian posterior probability scores (BIs) are reported in Figs 9 and S2-S4.

The phylogram based on the concatenated (COI, histone H3, and ITS) molecular dataset shows high ML and BI supports at all key nodes (Fig. 9). Clade I sensu Arrigoni et al. (2014) contains all species of Lobophyllia and Symphyllia analyzed so far and all our sequences of A.rowleyensis and $P$. vitiensis. The latter two species group together in a strongly supported lineage $(\mathrm{MLs}=100$ and BIs $=0.9)$ and their genetic boundaries remain unclear being indistinguishable from each other with these molecular markers. The average genetic distance of A. rowleyensis from $P$. vitiensis is $1.1 \pm 0.2 \%$, 


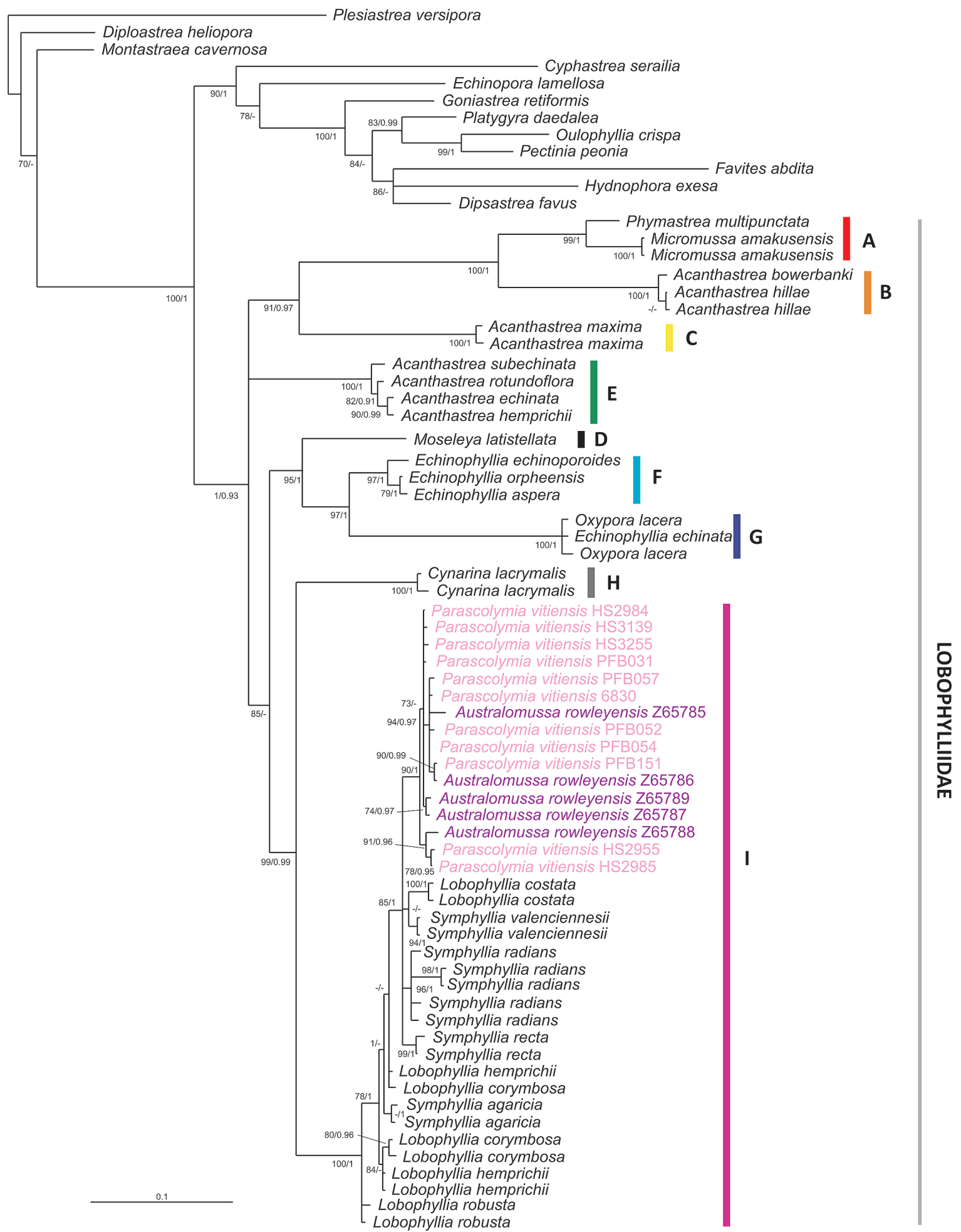

Fig. 9. Phylogenetic position of Parascolymia vitiensis and P. rowleyensis (previously Australomussa) and their relationships within the family Lobophylliidae based on concatenated matrix (COI, histone H3, and ITS region). Bayesian topology is shown. Numbers associated with branches indicate Maximum Likelihood bootstrap ( $>70 \%)$ support (left) and Bayesian posterior probabilities ( $>0.9)$ (right). Clades within Lobophylliidae are coloured and labelled A to I according to Arrigoni et al. (2014). 
while genetic variability within A. rowleyensis is $1.1 \pm$ $0.3 \%$ and within $P$. vitiensis is $0.7 \pm 0.2 \%$. The majority of the other species in this clade, L. costata (Dana, 1846), L. robusta Yabe, Sugiyama and Eguchi, 1936, $S$. agaricia Milne Edwards and Haime,1849, S. radians, S. recta (Dana, 1846), and S. valenciennesii Milne Edwards and Haime, 1849 are recovered as monophyletic lineages. The only exceptions are represented by $L$. corymbosa and L. hemprichii (Ehrenberg, 1834) that are not monophyletic and nested in two distinct lineages.

The Bayesian COI topology (Fig. S2) indicates that all newly obtained sequences of $A$. rowleyensis and $P$. vitiensis are nested together with the genera Lobophyllia and Symphyllia within clade I (MLs $=94 \%$ and BIs $=0.93$ ). While the two species are not monophyletic and they occur together in two main groups within clade I, the mitochondrial phylogenetic reconstruction is similar to that of the nuclear histone $\mathrm{H} 3$ (Fig. S3). Again, all newly obtained sequences of $A$. rowleyensis and $P$. vitiensis form clade I sensu Arrigoni et al. (2014) (MLs $=95 \%$ and BIs = -) together with several species of Lobophyllia and Symphyllia. Clade I is composed of 10 species represented by a total of 28 sequences, of which 26 share the same haplotype and they are thus identical, while the remaining two sequences differ from the others by only one bp substitution. Moreover, all of the Merulinidae subclades defined by Budd and Stolarski (2011) and Huang et al. (2011) are recovered with the exception of D/E. Interestingly, also in the family Lobophylliidae, all of the molecular clades defined by Arrigoni et al. (2014) based on COI and rDNA molecular markers, except F, are supported in our BI and ML analyses. The Bayesian topology obtained from the ITS region alignment is similar to both $\mathrm{COI}$ and histone H3ones, but has a higher resolution at species level with significant supports for the majority of key nodes (Fig. S4). Again, all our sequences of A. rowleyensis and $P$. vitiensis are found together in a strongly supported group $($ MLs $=90$ and BIs $=1)$ within clade I (Fig. S4). A similar situation is apparent for L. hemprichii and $S$. agaricia which occur in a strongly supported monophyletic group. The other Lobophyllia and Symphyllia species within clade I, i.e. L. costata, L. diminuta Veron, 1985, L. flabelliformis Veron, 2000, L. robusta, S. erythraea (Klunzinger, 1879), S. radians, $S$. recta, and $S$. valenciennesii, are recovered as monophyletic lineages, while the only specimen of Acanthastrea ishigakiensis Veron, 1990 is closely related to $S$. recta.

\section{Discussion}

In this study we explore the gross- and fine-scale morphology and the phylogeny of the two traditionally described monotypic genera Australomussa and Parascolymia. We provide a detailed description of diagnostic micromorphological characters of $A$. rowleyensis and $P$. vitiensis and we define the phylogenetic position of both these two species within the family Lobophylliidae using three molecular markers. As a result we propose a taxonomic revision for the genus Australomussa and we formally consider Australomussa as a junior synonym of Parascolymia.

Morphology of $\mathrm{P}$. rowleyensis and $\mathrm{P}$. vitiensis and consequences for taxonomy

The lack of genetic resolution between $P$. vitiensis and $P$. rowleyensis in all our molecular analyses might suggest that these two species are in fact synonyms. The skeleton morphology, however, indicates that although the two species share some macro- and micromorphologic character, they are morphologically distinct and they have a different state for 10 of the 21 characters used by Budd et al. (2012) (in bold in Table 1). Veron (1985) stated that Australomussa 'differs from Symphyllia in having an initial central corallite which buds daughter corallites extracalicularly, in lacking meandering valleys (which some Symphyllia ecomorphs also lack) and in having widely separated series of centres without a true common wall between them'. However, he provided no detailed information on the morphologic characters that differentiate Australomussa from Parascolymia (=Scolymia). Our observations of the macroand micromorphology of $P$. rowleyensis and $P$. vitiensis confirm that these species share a number of characters, namely intracalicular and extracalicular budding, corallite polymorphism associated with circumoral budding, uni or multiserial corallite integration, free septa, wide septa spacing with less than six septa per $5 \mathrm{~mm}$, discontinuous linkage between corallite centres (lamellar linkage), a trabecular spongy columella, a vesicular endotheca, septum tooth elliptical at the base, and irregular lobate tooth tips (Table 1). Nevertheless $P$. vitiensis has wider calices or series, a larger variability of continuity of costosepta over the wall, more cycles of septa, different relative costosepta thickness, a smaller columella size relative to calice width, higher and more widely spaced septum teeth, weakly developed septa granulation, a smoother inter-area structure, and unequal tooth shape between costosepta of different cycles 
(Table 1 in bold). We propose therefore that these morphological differences are sufficient to distinguish two species despite the fact that the unresolved genetic boundaries based on multiple markers strongly argue against retaining the species as distinct. Thus we formally consider Australomussa as a junior synonym of Parascolymia and retain $P$. vitiensis and $P$. rowleyensis as separate sister species.

In $P$. vitiensis the teeth in different septal cycles differ significantly in shape as already discussed by Veron and Pichon (1980) and Budd and Stolarski (2009). In $P$. rowleyensis the teeth in different septal cycles do not differ significantly in shape as described by Veron (1985) in the species original description. The type specimen of $P$. rowleyensis displays an obvious variability of thickening of costosepta between specimens as remarked by Veron (1985). However, the variability of shape and size of septal dentation is far more reduced in this species than in P. vitiensis. One of the specimens of $P$. rowleyensis in the series we examined, Z65786, has relatively thin septa and costosepta and is similar in this respect to the paratype WAM 17384 (Veron, 1985: Fig. 25). The remainder have a similar thickness of costosepta to the holotype WAM 17184 (Veron, 1985: Fig. 23). However, none of the specimens we examined in this study has radial elements as thick as paratype WAM 172-84 (Veron, 1985: Fig. 24). The thickness of radial elements of this paratype comes close to that of the radial elements of higher cycles of some $P$. vitiensis. Nevertheless, the number of septal cycles, and the relative thickness of septa from different cycles, as well as the size of the dentation of the septa fall within the range of $P$.rowleyensis rather than in that of $P$. vitiensis.

In some genera of lobophylliids (e.g. Lobophyllia, Symphyllia, Parascolymia), the teeth in different septal cycles differ significantly in shape while in other genera (e.g. Acanthastrea and Homophyllia) such differentiation is not observed (Budd and Stolarski, 2009). Our results confirm that the size and shape of septal teeth of $P$. vitiensis is highly variable within and between septa of the same specimen (Chevalier, 1975;

Table 1. Macromorphology and micromorphology of Parascolymia vitiensis and P. rowleyensis (previously Australomussa). Explanation of characters, their ID numbers (in brackets) and state names are from Budd et al. (2012).* = character examined on polycentric coralla; $\mathrm{Csn}=$ number of cycle of costosepta; $\mathrm{Sn}=$ number of cycle of septa. Names of characters which have different states in the two species in bold.

\begin{tabular}{|c|c|c|c|}
\hline & Character & P. vitiensis & $\begin{array}{l}\text { P. rowleyensis } \\
\text { (previously Australomussa) }\end{array}$ \\
\hline \multirow{13}{*}{ 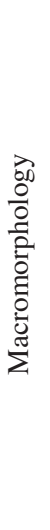 } & Intracalicular budding (1) & Present $*$ & Present \\
\hline & Extracalicular budding (2) & Present $*$ & Present \\
\hline & $\begin{array}{l}\text { Circumoral budding and associated } \\
\text { corallite polymorphism (3) }\end{array}$ & Present $*$ & Present \\
\hline & Corallite integration (4) & Uni or multiserial * & Uni or multiserial \\
\hline & Calice or valley width (7) & Large, $>2.5 \mathrm{~cm}$ & Large, $<2.5 \mathrm{~cm}$ \\
\hline & Continuity of costosepta (9) & Mostly not confluent $*$ & Mostly confluent \\
\hline & Number of septa (10) & 4 cycles & 6-7 cycles \\
\hline & Free septa (11) & Present & Present \\
\hline & Septa spacing (per $5 \mathrm{~mm})(12)$ & Wide, $<6$ & Wide, $<6$ \\
\hline & $\begin{array}{l}\text { Relative costosepta thickness } \\
(\text { Cs1andCs2 -) vs- Cs3) (13 }\end{array}$ & Unequal & Slightly unequal \\
\hline & Corallite centres linkage (14) & Discontinuous by lamellar linkage & Discontinuous by lamellar linkage \\
\hline & Columella structure (15) & Trabecular spongy & Trabecular spongy \\
\hline & Columella size relative to calice width (16) & Small, $<1 / 4$ & Small to medium, $\leq 1 / 4$ \\
\hline \multirow{8}{*}{ 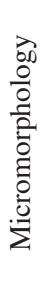 } & Endotheca (19) & Abundant/vesicular & Abundant/vesicular \\
\hline & Tooth base (mid-septum) (35) & Elliptical parallel & Elliptical parallel \\
\hline & Tooth tips (38) & Irregular lobate & Irregular lobate \\
\hline & Tooth height (S1) (39) & High, and $\geq 1 \mathrm{~mm}$ & High, but $<1 \mathrm{~mm}$ \\
\hline & Tooth spacing (S1) (40) & Very wide, $>2 \mathrm{~mm}$ & Wide, $1-2 \mathrm{~mm}$ \\
\hline & Granules shape and distribution (43) & Weak enveloped by thickening depositis & Strong scattered \\
\hline & Interarea structure (44) & Smooth and palisade & Palisade \\
\hline & Cs3/Cs1 tooth shape (45) & Unequal & Equal \\
\hline
\end{tabular}


Veron and Pichon, 1980; Budd and Stolarski, 2009) (Figs 4A-C, 5C-D, 7). The remarkable variation of these characters in $P$. vitiensis, and their within and between septa variability was also described by other authors (Veron and Pichon, 1980) and led Chevalier (1975) to describe the variety dentorotundata (namely, with rounded teeth) for some specimens from New Caledonia (e.g. Fig. 2B-C). However, in P. rowleyensis the variability in size and shape of septal teeth is much less developed, with septal and costoseptal teeth being of more uniform size and shape than in $P$. vitiensis (for $P$. rowleyensis see Figs 4D-F, 5A-B, 8).

\section{Molecular phylogeny of $\mathrm{P}$. rowleyensis and $\mathrm{P}$. vitiensis}

Our multi-locus molecular analyses showed that $P$. rowleyensis belongs to the family Lobophylliidae (Fig. 9), as proposed by Dai and Horng (2009) and Budd et al. (2012) based on the macromorphology of the colony and on traditional taxonomy (Veron, 1985, 1992, 2000). Moreover, the species, traditionally ascribed to the monotypic genus Australomussa, does not occur in a distinct molecular clade, rather it is nested within the well-supported clade I sensu Arrigoni at al. (2014), which comprises the genera Lobophyllia, Symphyllia, and Parascolymia (Fig. 9).

Parascolymia rowleyensis and $P$. vitiensis could not be separated in any single gene tree or the concatenated phylogeny (Figs 9, S2-S4) and the intraspecific and interspecific divergences within and between the two species completely overlap. The lack of genetic variation suggests that these two nominal species could be just one species or that lineage sorting is incomplete because the two species have a recent common ancestor. The former explanation is unlikely because $P$. rowleyensis and $P$. vitiensis differ in several micromorphological characters (Table 1) and, therefore, it is more likely these two species have not completely diverged although divergence time estimates are not available. An alternative hypothesis is hybridization between the two species, as reported for other genera (Diekmann et al., 2001; van Oppen et al., 2002; Vollmer and Palumbi, 2004; Richards et al., 2008). However, the lack of intra-individual polymorphism in nuclear sequences of both species and the absence of intermediate morphologies challenges this hypothesis.

\section{Utility of the examined molecular markers}

The three single gene trees gave congruent phylogeny reconstructions (Figs S2-S4), however higher resolu- tion at the species level was achieved by the ITS region (Fig. S4). The best overall BI and ML support was obtained for the concatenated dataset (Fig. 9).

The scleractinian COI gene is usually characterized by low evolution rate and consequently by an overlap of intraspecific and interspecific divergences that do not allow this marker to be used as a barcoding gene in the order Scleractinia (Hellberg, 2006; Shearer and Croffroth, 2008; Huang et al., 2008). The main exception to this general scenario in scleractian corals is Stylophora pistillata Esper, 1797, for which Keshavmurthy et al. (2013) detected four deeply divergent lineages corresponding to four particular geographic regions. COI can also be informative when combined or compared in multi-marker analyses (Fukami et al., 2008; Forsman et al., 2009; Huang et al., 2011; Benzoni et al., 2011, 2012a; Gittenberger et al., 2011) (Figs 4, S2). This mitochondrial region does however resolve the majority of the inner nodes, i.e. older relationships, within the family Lobophylliidae (this study and Arrigoni et al., 2012, 2014), Fungiidae Dana, 1846 (Gittenberger et al., 2011), and Poritidae Gray, 1842 (Kitano et al., 2014). In our phylogenetic reconstruction based on this mtDNA region, $P$. vitiensis and $P$. rowleyensis are nested within clade I (sensu Arrigoni et al., 2014) but they appear to be polyphyletic (Fig. S2). The intra-specific variability of $P$. vitiensis $(0.9 \pm$ $0.2 \%)$ and $P$. rowleyensis $(0.9 \pm 0.2 \%)$ overlaps the inter-specific distance between the two species $(0.9 \pm$ $0.2 \%$ ) and the last value is comparable to the mean closest congeneric inter-specific distances among Anthozoa $(0.71 \pm 0.15 \%)$ found by Huang et al. (2008).

The nuclear histone $\mathrm{H} 3$ gene has been extensively used in phylogenetic studies of arthropods (Colgan et al., 1998; Maxmen et al., 2003), annelids (Novo et al., 2011), and mollusks (Colgan et al., 2000; Pola and Gosliner, 2010) because it is easily amplifiable, highly conserved at the amino acid level, (transiently) highly expressed, and the presence of multiple histone repeats is an uncommon feature (Colgan et al., 1998, 2000; Maxson et al., 1983). It has recently been used in a coral phylogenetic analysis by Huang et al. (2011, 2014b) where it supported all higher-level lineages within the Merulinidae except clade D/E. Our phylogeny reconstruction based on histone $\mathrm{H} 3$ resolved all molecular clades within the Lobophylliidae with high node-support values (Fig. S3). These results suggest that histone $\mathrm{H} 3$ could be used to evaluate the broadbase phylogeny of other families, in both the Robust and Complex groups, and the phylogenetic relationships among their genera. 
The ITS region has been extensively used to resolve species boundaries in scleractinian corals (Diekmann et al., 2001; Forsmann et al., 2009; Benzoni et al., 2010, 2012b, 2014; Flot et al., 2011; Gittenberger et al., 2011; Stefani et al., 2011; Schmidt-Roachet al., 2012; Arrigoni et al., 2012, 2014; Keshavmurthy et al., 2013; Kitano et al., 2013, 2014). Despite the phylogenetic utility of this marker being questioned because of its unique pattern of secondary structure in the genus Acropora Oken, 1815 (van Oppen et al., 2002; Vollmer and Palumbi, 2004; Chen et al., 2004; Wei et al., 2006), it is currently accepted and considered as the most suitable molecular locus to resolve phylogenetic relationships among closely related species. Here, the ITS region resolved the majority of lobophylliid species (Fig. S4), except for species in clade E (Arrigoni et al., 2014). Within clade I (sensu Arrigoni et al., 2014) the majority of species included were monophyletic, with the notable exception of $P$. rowleyensis and $P$. vitiensis. Therefore, these results confirmed the usefulness of this marker in phylogentic studies and we strongly encourage its application for the delimitation of species boundaries in scleractinian corals until new highly variable markers are discovered.

In conclusion, this study demonstrated that comprehensive studies conducted both at molecular and micromorphological levels are and will be essential to evaluate the evolutionary relationships of scleractinian corals and their taxonomy. We strongly believe that different disciplines, such as morphology, molecular systematics, ecology, and reproduction, should be used for taxonomical studies to reach a more complete and comprehensive approach towards the understanding of coral species diversity and biogeography.

\section{Acknowledgments}

Collection during the CoralCal1 and CoralCal4 campaigns (IRD Noumea) was possible thanks to C Payri, J Butscher, A Arnaud, F Folcher, JL Menou, and the R/V Alis Captain R Proner and crew. We are grateful to E Karsenti (EMBL) and É Bourgois (Tara Expeditions) and the OCEANS consortium for sampling during the Tara Oceans expedition. We thank the commitment of the following people and sponsors who made this singular expedition possible: CNRS, EMBL, Genoscope/CEA, VIB, Stazione Zoologica Anton Dohrn, UNIMIB, ANR (projects POSEIDON/ ANR-09-BLAN-0348, BIOMARKS/ANR-08-BDVA-003, PROMETHEUS/ANR-09-GENM-031, and TARA-GIRUS/ ANR-09-PCS-GENM-218), EU FP7 (MicroB3/No.287589), FWO, BIO5, Biosphere 2, agnès b., the Veolia Environment Foundation, Region Bretagne, World Courier, Illumina, Cap L'Orient, the EDF Foundation EDF Diversiterre, FRB, the
Prince Albert II de Monaco Foundation, Etienne Bourgois, the Tara schooner and its captain and crew. Tara Oceans would not exist without continuous support from 23 institutes (http:// oceans.taraexpeditions.org). This article is contribution number 18 of the Tara Oceans Expedition 2009-2012. The Niugini Biodiversity Expedition and $\mathrm{P}$ Bouchet $(\mathrm{MNHN})$ are acknowledged for specimens from PNG. F Benzoni is deeply grateful to $\mathrm{C}$ Payri and B Dreyfus (IRD) for supporting her participation to this campaign. We thank CC Wallace (MTQ) and BW Hoeksema (RMNH) for museum support. R Arrigoni gratefully acknowledges the National Science Council of Taiwan (NSC) for his participation to Summer Program in Taiwan 2013 and the financial support of the European Commission's Research Infrastructure Action via the Synthesys Program for his visit to Naturalis Biodiversity Center (Leiden). Z Richards was supported in fieldwork and write-up phased by Woodside Energy and the Woodside Collection (Kimberley) project. Coral collection by AH Baird was funded by the ARC Centre of Excellence for Coral Reef Studies. The authors are grateful to the three anonymous reviewers for their help and constructive comments.

\section{References}

Arrigoni R, Stefani F, Pichon M, Galli P, Benzoni F. 2012. Molecular phylogeny of the Robust clade (Faviidae, Mussidae, Merulinidae, and Pectiniidae): An Indian Ocean perspective. Molecular Phylogenetics and Evolution 65: 183-193.

Arrigoni R, Terraneo TI, Galli P, Benzoni F. 2014. Lobophylliidae (Cnidaria, Scleractinia) reshuffled: pervasive non-monophyly at genus level. Molecular Phylogenetics and Evolution 73: 60-64.

Benzoni F. 2006. Psammocora albopicta sp. nov., a new species of scleractinian coral from the Indo-West Pacific (Scleractinia; Siderastreidae). Zootaxa 1358: 49-57.

Benzoni F, Stefani F, Pichon M, Galli P. 2010. The name game: morpho-molecular species boundaries in the genus Psammocora (Cnidaria, Scleractinia). Zoological Journal of the Linnean Society 160: 421-456.

Benzoni F, Arrigoni R, Stefani F, Pichon M. 2011. Phylogeny of the coral genus Plesiastrea (Cnidaria, Scleractinia). Contributions to Zoology 80: 231-249.

Benzoni F, Arrigoni R, Stefani F, Stolarski J. 2012a.Systematics of the coral genus Craterastrea (Cnidaria, Anthozoa, Scleractinia) and description of a new family through combined morphological and molecular analyses. Systematics and Biodiversity 10: 417-433.

Benzoni F, Arrigoni R, Stefani F, Reijnen BT, Montano S, Hoeksema BW. 2012b. Phylogenetic position and taxonomy of Cycloseris explanulata and $C$. wellsi (Scleractinia: Fungiidae): lost mushroom corals find their way home. Contributions to Zoology 81: 125-146.

Benzoni F, Arrigoni R, Waheed Z, Stefani F, Hoeksema BW. 2014. Phylogenetic relationships and revision of the genus Blastomussa (Cnidaria: Anthozoa: Scleractinia) with description of a new species. Raffles Bulletin of Zoology 62: 358-378.

Brüggemann F. 1877. Notes on stony corals in the British Museum. III. A revision of recent solitary Mussaceae. The Annals and Magazine of Natural History Series 4: 300-12. 
Budd AF, Stolarski J. 2009. Searching for new morphological characters in the systematics of scleractinian reef corals: comparison of septal teeth and granules between Atlantic and Pacific Mussidae. Acta Zoologica 90: 142-165.

Budd AF, Stolarski J. 2011. Corallite wall and septal microstructure in scleractinian reef corals: comparison of molecular clades within the family Faviidae. Journal of Morphology 272: 66-88.

Budd AF, Fukami H, Smith N, Knowlton N. 2012. Taxonomic classification of the reef coral family Mussidae (Cnidaria: Anthozoa: Scleractinia). Zoological Journal of the Linnean Society 166: 465-529.

Chen CA, Wallace CC, Wolstenholme J. 2002. Analysis of the mitochondrial $12 \mathrm{~S}$ rRNA gene supports a two-clade hypothesis of the evolutionary history of scleractinian corals. Molecular Phylogenetics and Evolution 23: 137-149.

Chen CC, Chang CC, Wei NV, Chen CH, Lein YT, Dai CF, Wallace C. 2004. Secondary structure and phylogenetic utility of ribosomal internal spacer 2 (ITS2) in Scleractinian corals. Zoological Studies 43: 759-771.

Chevalier JP. 1975. Les Scléractiniaires de la Mélanésie Française (Nouvelle-Calédonie, Iles Chesterfield, Iles Loyauté, Nouvelles Hébrides). Expédition Francaise Sur les Récifs Coralliens de la Nouvelle-Calédonie, Deuxieme Partie 7: 1-407.

Colgan DJ, McLauchlan A, Wilson GDF, Livingston SP, Edgecombe GD, Macaranas J, Cassis G, Gray MR. 1998. Histone H3 and U2 snRNA DNA sequences and arthropod molecular evolution. Australian Journal of Zoology 46: 419-437.

Colgan DJ, Ponder WF, Eggler PE. 2000. Gastropod evolutionary rates and phylogenetic relationships assessed using partial 28S rDNA and histone H3 sequences. Zoologica Scripta 29: 29-63.

Crossland C. 1952. Madreporaria, Hydrocorallinae, Heliopora and Tubipora. Great Barrier Reef Exped. 1928-29. Catalogue of the Madreporarian Corals in the British Museum (Natural History) 6: 85-257.

Dai CF, Horng S. 2009. Scleractinia fauna of Taiwan II. The robust group. Taipei: National Taiwan University. pp. 1-162.

Diekmann OE, Bak RPM, Stam WT, Olsen JL. 2001. Molecular genetic evidence for probable reticulate speciation in the coral genus Madracis from a Caribbean fringing reef slope. Marine Biology 139: 221-233.

Flot JF, Blanchot J, Charpy L, Cruaud C, Licuanan WY, Nakano Y, Payri C, Tillier S. 2011. Incongruence between morphotypes and genetically delimited species in the coral genus Stylophora: phenotypic plasticity, morphological convergence, morphological stasis or interspecific hybridization? BMC Ecology 11: 22.

Forsman ZH, Barshis DJ, Hunter CL, Toonen RJ. 2009. Shapeshifting corals: molecular markers show morphology is evolutionary plastic in Porites. BMC Evolutionary Biology 9: 45.

Fukami H, Budd AF, Paulay G, Solé-Cava A, Chen CA, Iwao K, Knowlton N. 2004. Conventional taxonomy obscures deep divergence between Pacific and Atlantic corals. Nature 427: 832-835.

Fukami H, Chen CA, Budd AF, Collins A, Wallace C, Chuang YY, Chen C, Dai CF, Iwao K, Sheppard C, Knowlton N. 2008. Mitochondrial and nuclear genes suggest that stony corals are monophyletic but most families of stony corals are not (Order Scleractinia, Class Anthozoa, Phylum Cnidaria). PLOS ONE 3: e3222.
Gardiner JS. 1899. On the solitary corals, collected by Dr. A. Willey Zoological Results based on Material from New Britain, New Guinea, Loyalty Islands and Elsewhere 2: 161-180.

Gittenberger A, Reijnen BT, Hoeksema BW. 2011. A molecularly based phylogeny reconstruction of mushroom corals (Scleractinia: Fungiidae) with taxonomic consequences and evolutionary implications for life history traits. Contributions to Zoology 80: 107-132.

Guindon S, Gascuel O. 2003. A simple, fast, and accurate algorithm to estimate large phylogenies by maximum likelihood. Systematic Biology 52: 696-704.

Hall TA. 1999. BioEdit: a user-friendly biological sequence alignment editor analysis program for Windows 95/98/NT. Nucleic Acids Symposium Series 41: 95-98.

Hellberg M. 2006. No variation and low synonymous substitution rates in coral mtDNA despite high nuclear variation. BMC Evolutionary Biology 6: 24.

Hoeksema BW. 2007. Delineation of the Indo-Malayan Centre of Maximum Marine Biodiversity: The Coral Triangle. Pp. 117-178 in: Renema W, ed., Biogeography, Time and Place: Distributions, Barriers and Islands.

Hoeksema BW. 2014. The "Fungia patella group" (Scleractinia, Fungiidae) revisited with a description of the mini mushroom coral Cycloseris boschmai sp. n. Zookeys 371: 57-84.

Huang D, Meier R, Todd PA, Chou LM. 2008. Slow mitochondrial COI sequence evolution at the base of the metazoan tree and its implications for DNA barcoding. Journal of Molecular Evolution 66: 167-174.

Huang D, Licuanan WY, Baird AH, Fukami H. 2011. Cleaning up the "Bigmessidae": molecular phylogeny of scleractinian corals from Faviidae, Merulinidae, Pectiniidae, and Trachyphylliidae. BMC Evolutionary Biology 11: 37.

Huang D, Benzoni F, Fukami H, Knowlton N, Smith ND, Budd AF. 2014a. Taxonomic classification of the reef coral families Merulinidae, Montastraeidae, and Diploastraeidae (Cnidaria: Anthozoa: Scleractinia). Zoological Journal of the Linnean Society 171: 277-355.

Huang D, Benzoni F, Arrigoni R, Baird AH, Berumen ML, Bouwmeester J, Chou LM, Fukami H, Licuanan WY, Lovell ER, Meier R, Todd PA, Budd AF. 2014b. Towards a phylogenetic classification of reef corals: the Indo-Pacific genera Merulina, Goniastrea and Scapophyllia (Scleractinia, Merulinidae). Zoologica Scripta 43: 531-548.

Katoh K, Misawa K, Kuma K, Miyata T. 2002. MAFFT: a novel method for rapid multiple sequence alignment based on fast Fourier transform. Nucleic Acids Research 30: 3059-3066.

Katoh K, Standley DM. 2013. MAFFT multiple sequence alignment software version 7: improvements in performance and usability. Molecular Biology and Evolution 30: 772-780.

Keshavmurthy S, Yang SY, Alamaru A, Chuang YY, Pichon M, Obura DO, Silvia S, De Palmas S, Stefani F, Benzoni F, MacDonald A, Noreen AME, Chen C, Wallace CC, Pillay R, Denis V, Amri AY, Reimer JD, Mezaki T, Sheppard C, Loya Y, Abelson A, Mohammed MS, Baker AC, Mostafavi PG, Suharsono BA, Chen CA. 2013. DNA barcoding reveals the coral "laboratory-rat", Stylophora pistillata encompasses multiple identities. Scientific Reports 3: 1520.

Kitahara MV, Cairns SD, Stolarski J, Blair D, Miller DJ. 2010. A comprehensive phylogenetic analysis of the Scleractinia (Cnidaria, Anthozoa) based on mitochondrial CO1 sequence data. PLOS ONE 5: e11490. 
Kitahara MV, Stolarski J, Cairns SD, Benzoni F, Stake JL, Miller DJ. 2012. The first modern solitary Agariciidae (Anthozoa, Scleractinia) revealed by molecular and microstructural analysis. Invertebrate Systematics 26: 303-315.

Kitahara MV, Cairns SD, Stolarski J, Miller DJ. 2013. Deltocyathiidae, an early diverging family of Robust corals (Anthozoa, Scleractinia). Zoologica Scripta 42: 201-212.

Kitano YF, Obuchi M, Uyeno D, MiyazakiK, Fukami H. 2013. Phylogenetic and taxonomic status of the coral Goniopora stokesi and related species (Scleractinia: Poritidae) in Japan based on molecular and morphological data. Zoological Studies 52: 1-16.

Kitano YF, Benzoni F, Arrigoni R, Shirayama Y, Wallace CC, Fukami H. 2014. A phylogeny of the family Poritidae (Cnidaria, Scleractinia) based on molecular and morphological analyses. PLOS ONE 9: e98406.

Kozub D, Khmelik V, Shapoval J, Chentsov V, Yatsenko S, Litovchenko B, Starikh V. 2000-2012. Helicon Focus 5.3. Elicon Soft Ltd.

Librado P, Rozas J. 2009. DnaSP v5: a software for comprehensive analysis of DNA polymorphism data. Bioinformatics 25: 1451-1452.

Matthai G. 1928. A monograph of the recent meandroid Astraeidae. Catalogue of the Madreporarian Corals in the British Museum (Natural History) 7: 1-288.

Maxmen AB, King BF, Cutler EB, Giribet G. 2003. Evolutionary relationships within the protostome phylum Sipuncula: a molecular analysis of ribosomal genes and histone $\mathrm{H} 3$ sequence data. Molecular Phylogenetics and Evolution 27: 489-503.

Maxson R, Cohn R, Kedes L, Mohun T. 1983. Expression and organization of histone genes. Annual Review of Genetics 17: 239-277.

Novo M, Almodóvar A, Fernández R, Giribet G, Díaz Cosín DJ. 2011. Understanding the biogeography of a group of earthworms in the Mediterranean basin - The phylogenetic puzzle of Hormogastridae (Clitellata: Oligochaeta). Molecular Phylogenetics and Evolution 61: 125-135.

Nylander JAA. 2004. MrModeltest v2. Program distributed by the author. Evolutionary Biology Centre, Uppsala University.

Oppen MJ van, Willis BL, Van Rheede T, Miller DJ. 2002. Spawning times, reproductive compatibilities and genetic structuring in the Acropora aspera group: evidence for natural hybridization and semi-permeable species boundaries in corals. Molecular Ecology 11: 1363-1376.

Pola M, Gosliner TM. 2010. The first molecular phylogeny of cladobranchian opisthobranchs (Mollusca, Gastropoda, Nudibranchia). Molecular Phylogenetics and Evolution 56: 931-941.

Rambaut A, Drummond AJ. 2007. Tracer v1.4. http://beast.bio. ed.ac.uk/Tracer

Richards ZT, van Oppen MJH, Wallace CC, Willis BL, Miller DJ. 2008. Some rare Indo-Pacific coral species are probable hybrids. PLOS ONE 3: e3240.

Richards ZT, Wallace CC, Miller DJ. 2013. Molecular phylogenetics of geographically restricted Acropora species: Implications for conservation. Molecular Phylogenetics and Evolution 69: 837-851.

Romano SL, Palumbi SR. 1996. Evolution of scleractinian corals inferred from molecular systematic. Science 271: 640-642.

Ronquist F, Huelsenbeck JP. 2003. MrBayes 3: Bayesian phylogenetic inference under mixed models. Bioinformatics 19: 1572-1574.
Schmidt-Roach S, Lundgren P, Miller KJ, Gerlach G, Noreen A, Andreakis N. 2012. Assessing hidden speciesdiversity in the coral Pocillopora damicornis from Eastern Australia. Coral Reefs 32: 1-12.

Schmidt-Roach S, Miller KJ, Andreadkis N. 2013. Pocillopora aliciae: a new species of scleractinian coral (Scleractinia, Pocilloporidae) from subtropical Eastern Australia. Zootaxa 3626: 576-582.

Schmidt-Roach S, Miller KJ, Lundgren P, Andreakis N. 2014. With eyes wide open: a revision of species within and closely related to the Pocillopora damicornis species complex (Scleractinia; Pocilloporidae) using morphology and genetics. Zoological Journal of the Linnean Society 170: 1-33.

Shearer TL, Coffroth A. 2008. Barcoding corals: limited by interspecific divergence, not intraspecific variation. Molecular Ecology 8: 247-255.

Souter P. 2010. Hidden genetic diversity in a key model species of coral. Marine Biology 157: 875-885.

Stefani F, Benzoni F, Pichon M, Cancelliere C, Galli P. 2008. A multidisciplinary approach to the definition of species boundaries in branching species of the coral genus Psammocora (Cnidaria, Scleractinia). Zoologica Scripta 37: 71-91.

Stefani F, Benzoni F, Yang SY, Pichon M, Galli P, Chen CA. 2011. Comparison of morphological and genetic analyses reveals cryptic divergence and morphological plasticity in Stylophora (Cnidaria, Scleractinia). Coral Reefs 30: 1033 1049.

Stolarski J, Kitahara MV, Miller DJ, Cairns SD, Mazur M, Meibom A. 2011. The ancient evolutionary origins of Scleractinia revealed by azooxanthellate corals. BMC Evolutionary Biology 11: 316.

Swofford DL. 2003. PAUP. Phylogenetic Analysis Using Parsimony (and other methods). Version 4. Sinauer Associates, Sunderland, Massachusetts.

Takabayashi M, Carter DA, Loh WKW, Hoegh-Guldberg O. 1998. A corals pecific primer for PCR amplifications of the internal transcribed spacer region in ribosomal DNA. Molecular Ecology 7: 928-930.

Tamura K, Peterson D, Peterson N, Stecher G, Nei M, Kumar S. 2011. MEGA5: molecular evolutionary genetics analysis using Maximum Likelihood, Evolutionary Distance, and Maximum Parsimony method. Molecular Biology and Evolution 28: 2731-2739.

Vaughan TW, Wells JW. 1943. Revision of the suborders, families, and genera of the Scleractinia. Geological Society of America, Special Paper 44: 1-363.

Veron JEN. 1985. New Scleractinia from Australian coral reefs. Records of the Western Australian Museum 12: 147-183.

Veron JEN. 1992. Hermatypic corals of Japan. Australian Institute of Marine Science, Townsville.

Veron JEN. 2000. Corals of the world. Australian Institute of Marine Science, Townsville.

Veron JEN, Pichon M. 1980. Scleractinia of Eastern Australia. Part 3, Families Agariciidae, Siderastreidae, Fungiidae, Oculinidae, Merulinidae, Mussidae, Pectiniidae, Caryophylliidae, Dendrophyliidae. Australian Institute of Marine Science Monograph Series 4: 1-422.

Veron JEN, Devantier LM, Turak E, Green AL, Kininmonth S, Stafford-Smith M, Peterson N. 2009. Delineating the Coral Triangle. Galaxea, Journal of Coral Reef Studies 11: 91100 
Vollmer SV, Palumbi SR. 2004. Testing the utility of internally transcribed spacer sequences in coral phylogenetics. Molecular Ecology 13: 2763-2772.

Wallace CC, Chen CA, Fukami H, Muir PR. 2007. Recognition of separate genera within Acropora based on new morphological, reproductive and genetic evidence from Acropora togianensis, and elevation of the subgenus Isopora Studer, 1878 to genus (Scleractinia: Astrocoeniidae; Acroporidae). Coral Reefs 26: 231-239.

Wei NWV, Wallace CC, Dai CF, Pillay KRM, Chen CA. 2006. Analyses of the ribosomal Internal Transcribed Spacers (ITS) and the 5.8S gene indicate that extremely high rDNA heterogeneity is a unique feature in the scleractinian coral genus Acropora (Scleractinia; Acroporidae). Zoological Studies 45: 404-418.
Wells JW. 1937. Coral studies. I Two new species of fossil corals. II Five new genera of the Madreporaria. Bulletins of American Paleontology 23: 238-253.

Wells JW. 1964. The recent solitary mussid scleractinian corals. Zoologische Mededelingen 39: 375-384.

White TJ, Bruns T, Lee S, Taylor J. 1990. Amplification and direct sequencing of fungal ribosomal RNA genes for phylogenetics. Pp. 315-322 in: Innis MA, Gelfand DH, Sninsky JJ, White TJ, eds, PCR Protocols. A Guide to Methods and Application. San Diego, California: Academic Press Inc.

Received: 9 April 2014

Revised and accepted: 24 June 2014

Published online: 29 August 2014

Editor: R.W.M. van Soest

\section{On-line Supplementary Information}

S1. List of the material examined in this study. For each specimen we list code, identification, molecular clade within the Lobophylliidae, sampling locality, collector, and COI, histone H3, and ITS region sequences used for the phylogenetic reconstructions.

S2. Phylogenetic position of Parascolymia vitiensis and P. rowleyensis (previously Australomussa) within the family Lobophylliidae based on partial mitochondrial COI gene. Bayesian topology is shown. Numbers associated with branches indicate Maximum Likelihood bootstrap (>70\%) support (left) and Bayesian posterior probabilities $(>0.9)$ (right). Clades within Lobophylliidae are coloured and labelled A to I according to Arrigoni et al. (2014).

S3. Phylogenetic position of Parascolymia vitiensis and P. rowleyensis (previously Australomussa) within the family Lobophylliidae based on nuclear histone H3. Bayesian topology is shown. Numbers associated with branches indicate Maximum Likelihood bootstrap (>70\%) support (left) and Bayesian posterior probabilities ( $>0.9)$ (right). Clades within Lobophylliidae are coloured and labelled A to I according to Arrigoni et al. (2014).

S4. Phylogenetic relationships between Parascolymia vitiensis and P. rowleyensis (previously Australomussa) within the family Lobophylliidae based on nuclear ITS region. Bayesian topology is shown. Numbers associated with branches indicate Maximum Likelihood bootstrap (>70\%) support (left) and Bayesian posterior probabilities $(>0.9)$ (right). Clades within Lobophylliidae are coloured and labelled A to I according to Arrigoni et al. (2014).

S5. In situ photos of the specimens of Parascolymia vitiensis analyzed in this study: A) 6816, B) 6830; C) IRD HS2955; D) IRD HS2964; E) IRD HS2985, F) IRD HS3255; G) UNIMIB PFB031; H) UNIMIB PFB032; I) UNIMIB PFB033; J) UNIMIB PFB052; K) UNIMIB PFB053; L) UNIMIB PFB055; M) UNIMIB PFB151; N) UNIMIB PFB152. 


\section{Appendix}

Based on the aforementioned molecular data and morphologic observations discussed above, Australomus$s a$ is considered a junior synonym of Parascolymia and $A$. rowleyensisis is hereafter formally moved to this genus.

Family Lobophylliidae Dai and Horng, 2009

Genus Parascolymia Wells, 1964

Type species. Scolymia vitiensis Brüggemann, 1877: 304

Revised diagnosis. Corallum attached, monocentric or polycentric by intracalicular and extracalicular budding. Corallite can display polymorphism. Corallite integration uni or multiserial. Calice or valley width is large (see Budd et al., 2012). Continuity of costosepta mostly confluent in policentric coralla. Septa of the last cycle free. Septa spacing large. Relative costosepta thickness between Cs 1 and Cs 2 versus $\mathrm{Cs} 3$ unequal or slightly unequal. In polycentric coralla linkage between centres of adjacent corallites within series is lamellar. Columella trabecular and spongy. Endotheca vesicular. Septal tooth base at mid-septum is elliptical in shape and parallel to the direction of the septum. Tooth tips irregular and lobate. Teeth on S1 high and their spacing is wide. The inter-area structure is generally smooth or with palisade. Tooth shape between Cs3 and Cs1 equal or unequal.

Parascolymia vitiensis (Brüggemann, 1877)

Scolymia vitiensis Brüggemann, 1877, p. 304; Veron 2000, p. 68, figs 1-7; Dai and Horng, 2009, p. 71, figs 1-2; Turak and DeVantier, 2011, p. 174.

Scolymia cf vitiensis Veron and Pichon, 1980, pp. 244250, figs 410, 411, 413-417.

Parascolymia vitiensis (Brüggemann, 1877) Budd and Stolarski, 2009, figs 2, 4, 6-7, 9, 11; Budd et al., 2012, fig 4; Arrigoni et al., 2014, fig 2.

Holotype: (NHMUK 1862.2.4.49) from Fiji, dry specimen.

Parascolymia rowleyensis (Veron, 1985)

Australomussa rowleyensis Veron, 1985, p.171, figs 23-25; Veron, 2000, p. 80, figs 1-5; Dai and Horng, 2009, p. 69, figs 1-2; Turak and DeVantier, 2011, p. 175.

Holotype: (WAM Z907) from Legendre Island, Dampier Archipelago, Western Australia, dry specimen. Paratypes: (WAM 172-84) from Mermaid Reef, Row- ley Shoals, Western Australia, dry specimen, (WAM 183-84) from Phuket Peninsula, western Thailand, dry specimen.

\section{Examined material}

Parascolymia vitiensis (Brüggemann, 1877)

Australia - (AIMS monograph coral collection, Coll. M. Pichon and J.E.N. Veron): MTQ G43171 Esk Island, Palm Islands, QLD (1846'S; 146 $31^{\circ}$ 'E), 1-22m; MTQ G43207 Hook Island, Whitsunday Islands, QLD (2004'S; 148 $\left.57^{\circ} \mathrm{E}\right), 2-8 \mathrm{~m}$; (Coll. A. Baird): 6830 Great Barrier Reef, Orpheus Island, Little Pioneer Bay (18³6'S, $146^{\circ} 29^{\prime}$ E), 23/05/2013; 6816 Great Barrier Reef, Orpheus Island, Little Pioneer Bay (18 $36^{\circ} \mathrm{S}$, $146^{\circ} 29^{\prime}$ E), 23/05/2013; Papua New Guinea - (NIUGINI, Coll. F. Benzoni): UNIMIB PFB031, site PCT50, 10/11/2012; UNIMIB PFB032, PCT50, 10/11/2012; UNIMIB PFB052, PCT44 Kranget Island (-5,18927; 145,8273), 11/11/2012; UNIMIB PFB053, PCT44 Kranget Island (-5,18927; 145,8273), 11/11/2012; UNIMIB PFB054, PCT44 Kranget Island $(-5,18927$; 145,8273), 11/11/2012; UNIMIB PFB055, PCT44 Kranget Island $(-5,18927 ; 145,8273), 11 / 11 / 2012$; UNIMIB PFB056 PCT44 Kranget Island (-5,18927; 145,8273), 11/11/2012; UNIMIB PFB057, PCT44 Kranget Island $(-5,18927 ; 145,8273), 11 / 11 / 2012$; UNIMIB PFB151, PCT29, Paeowa Island (-5,1745; 145,8334), 13/11/2012; PFB152, PCT29 Paeowa Island $(-5,1745 ; 145,8334), 13 / 11 / 2012$; New Caledonia (CC1, Coll. F. Benzoni and G. Lasne): IRD HS1440, ST1069, 19/03/2007; IRD HS1443, ST1069, 19/03/2007; IRD HS1452, ST1069, 19/03/2007; IRD HS1456, ST1069, 19/03/2007 - (CCAP, Coll. F. Benzoni and G. Lasne): IRD HS1722, ST1117, 30/10/2007; IRD HS1740, ST1119, 31/10/2007; IRD HS1796, ST1121,01/11/2007; IRD HS1812, ST1123, 02/11/2007(CC4, Coll. F. Benzoni): IRD HS2955, ST1452, 06/04/2012; IRD HS2964, ST1453, 06/04/2012; IRD HS2984, ST1455, 07/04/2012; IRD HS2985, ST1455, 07/04/2012; IRD HS3139, ST 1469, 16/04/2012; IRD HS3255, ST 1479, 22/04/2012.

Parascolymia rowleyensis (Veron, 1985)

Australia - (Woodside Collection (Kimberley) Expeditions 2009-2012, Coll. Z. Richards): WAM Z65785, Stn. $114 / \mathrm{K} 12$, Patricia Is. $\left(14.25 .298^{\circ} \mathrm{S} ; 125.30 .443^{\circ} \mathrm{E}\right)$ 12m, 22/10/2012 (K10); WAM Z65789, Stn. 6, Adele Is. (15.26.676 $\left.\mathrm{S} ; 123.10 .249^{\circ} \mathrm{E}\right) 12 \mathrm{~m}, 15 / 10 / 2009$ (K60); 
WAM Z65788, Stn. 9/K12, Adele Is. (15.30.248 ${ }^{\circ} \mathrm{S}$; $\left.123.05 .766^{\circ} \mathrm{E}\right) 12 \mathrm{~m}, 16 / 10 / 2009$ (K93); WAM Z65787, Stn. 75/K12, Beagle Reef (15.35.217S; $\left.123.53 .654^{\circ} \mathrm{E}\right)$ 12m, 20/10/2011 (K94); WAM Z65786, Stn. 78/K12, Mavis Reef $\left(15.50 .519^{\circ} \mathrm{S} ; 123.60 .824^{\circ} \mathrm{E}\right) 12 \mathrm{~m}$, 21/10/2012 (K141); Solomon Islands - (Coll. E. Turak) MTQ G57901 Santa Isabel Island, Palunuhukura
(0750.8'S; $\left.158^{\circ} 43.3^{\prime} \mathrm{E}\right), 2-26 \mathrm{~m}, 16 / 05 / 2004$; Indonesia - (Coll. B.W. Hoeksema) RMNH Coel. 23309, W Sumatra, off Padang, Gusung Sipakal reef, 02/05/1995; RMNH Coel. 24941, SW Sulawesi, Spermonde Archipelago, Kudingareng Keke reef, 22/05/1996; RMNH Coel. 24178, SW Sulawesi, Spermonde Archipelago, Bone Lola reef, 11m, 05/03/1996. 
S1. List of the material examined in this study. For each specimen we list code, identification, molecular clade within the Lobophyllliidae, sampling locality, collector, and COI, histone H3, and ITS region sequences used for the phylogenetic reconstructions.

\begin{tabular}{|c|c|c|c|c|c|c|c|}
\hline Code & Species & Clade & $\begin{array}{l}\text { Sampling } \\
\text { locality }\end{array}$ & Collector & $\mathrm{COI}$ & H3 & ITS region \\
\hline $\begin{array}{l}\text { WAM } \\
\text { Z65785 }\end{array}$ & $\begin{array}{l}\text { Australomussa } \\
\text { rowleyensis }\end{array}$ & I & Australia & Z. Richards & LK022344 & LK022380 & LK022359 \\
\hline $\begin{array}{l}\text { WAM } \\
\text { Z65786 }\end{array}$ & $\begin{array}{l}\text { Australomussa } \\
\text { rowleyensis }\end{array}$ & I & Australia & Z. Richards & LK022345 & LK022381 & LK022360 \\
\hline $\begin{array}{l}\text { WAM } \\
\text { Z65787 }\end{array}$ & $\begin{array}{l}\text { Australomussa } \\
\text { rowleyensis }\end{array}$ & I & Australia & Z. Richards & LK022346 & LK022382 & LK022361 \\
\hline $\begin{array}{l}\text { WAM } \\
\text { Z65788 }\end{array}$ & $\begin{array}{l}\text { Australomussa } \\
\text { rowleyensis }\end{array}$ & I & Australia & Z. Richards & LK022347 & LK022383 & LK022362 \\
\hline $\begin{array}{l}\text { WAM } \\
\text { Z65789 }\end{array}$ & $\begin{array}{l}\text { Australomussa } \\
\text { rowleyensis }\end{array}$ & I & Australia & Z. Richards & LK022348 & LK022384 & LK022363 \\
\hline 6816 & $\begin{array}{l}\text { Parascolymia } \\
\text { vitiensis }\end{array}$ & I & Australia & A. Baird & & LK022385 & LK022364 \\
\hline 6830 & $\begin{array}{l}\text { Parascolymia } \\
\text { vitiensis }\end{array}$ & I & Australia & A. Baird & LK022349 & LK022386 & LK022365 \\
\hline $\begin{array}{l}\text { IRD } \\
\text { HS2955 }\end{array}$ & $\begin{array}{l}\text { Parascolymia } \\
\text { vitiensis }\end{array}$ & I & $\begin{array}{l}\text { New } \\
\text { Caledonia }\end{array}$ & F. Benzoni & LK022350 & LK022387 & LK022366 \\
\hline $\begin{array}{l}\text { IRD } \\
\text { HS2964 }\end{array}$ & $\begin{array}{l}\text { Parascolymia } \\
\text { vitiensis }\end{array}$ & I & $\begin{array}{l}\text { New } \\
\text { Caledonia }\end{array}$ & F. Benzoni & LK022351 & & LK022367 \\
\hline $\begin{array}{l}\text { IRD } \\
\text { HS2984 }\end{array}$ & $\begin{array}{l}\text { Parascolymia } \\
\text { vitiensis }\end{array}$ & I & $\begin{array}{l}\text { New } \\
\text { Caledonia }\end{array}$ & F. Benzoni & LK022352 & LK022388 & LK022368 \\
\hline $\begin{array}{l}\text { IRD } \\
\text { HS2985 }\end{array}$ & $\begin{array}{l}\text { Parascolymia } \\
\text { vitiensis }\end{array}$ & I & $\begin{array}{l}\text { New } \\
\text { Caledonia }\end{array}$ & F. Benzoni & LK022353 & LK022389 & LK022369 \\
\hline $\begin{array}{l}\text { IRD } \\
\text { HS3139 }\end{array}$ & $\begin{array}{l}\text { Parascolymia } \\
\text { vitiensis }\end{array}$ & I & $\begin{array}{l}\text { New } \\
\text { Caledonia }\end{array}$ & F. Benzoni & LK022354 & LK022390 & LK022370 \\
\hline $\begin{array}{l}\text { IRD } \\
\text { HS3255 }\end{array}$ & $\begin{array}{l}\text { Parascolymia } \\
\text { vitiensis }\end{array}$ & I & $\begin{array}{l}\text { New } \\
\text { Caledonia }\end{array}$ & F. Benzoni & HF954202 & LK022391 & HF954289 \\
\hline $\begin{array}{l}\text { UNIMIB } \\
\text { PFB031 }\end{array}$ & $\begin{array}{l}\text { Parascolymia } \\
\text { vitiensis }\end{array}$ & I & $\begin{array}{l}\text { Papua New } \\
\text { Guinea }\end{array}$ & F. Benzoni & HF954203 & LK022392 & HF954290 \\
\hline $\begin{array}{l}\text { UNIMIB } \\
\text { PFB032 }\end{array}$ & $\begin{array}{l}\text { Parascolymia } \\
\text { vitiensis }\end{array}$ & I & $\begin{array}{l}\text { Papua New } \\
\text { Guinea }\end{array}$ & F. Benzoni & & LK022393 & LK022371 \\
\hline $\begin{array}{l}\text { UNIMIB } \\
\text { PFB033 }\end{array}$ & $\begin{array}{l}\text { Parascolymia } \\
\text { vitiensis }\end{array}$ & I & $\begin{array}{l}\text { Papua New } \\
\text { Guinea }\end{array}$ & F. Benzoni & & & LK022372 \\
\hline $\begin{array}{l}\text { UNIMIB } \\
\text { PFB052 }\end{array}$ & $\begin{array}{l}\text { Parascolymia } \\
\text { vitiensis }\end{array}$ & I & $\begin{array}{l}\text { Papua New } \\
\text { Guinea }\end{array}$ & F. Benzoni & LK022355 & LK022394 & LK022373 \\
\hline $\begin{array}{l}\text { UNIMIB } \\
\text { PFB053 }\end{array}$ & $\begin{array}{l}\text { Parascolymia } \\
\text { vitiensis }\end{array}$ & I & $\begin{array}{l}\text { Papua New } \\
\text { Guinea }\end{array}$ & F. Benzoni & & & LK022374 \\
\hline $\begin{array}{l}\text { UNIMIB } \\
\text { PFB054 }\end{array}$ & $\begin{array}{l}\text { Parascolymia } \\
\text { vitiensis }\end{array}$ & I & $\begin{array}{l}\text { Papua New } \\
\text { Guinea }\end{array}$ & F. Benzoni & LK022356 & LK022395 & LK022375 \\
\hline $\begin{array}{l}\text { UNIMIB } \\
\text { PFB055 }\end{array}$ & $\begin{array}{l}\text { Parascolymia } \\
\text { vitiensis }\end{array}$ & I & $\begin{array}{l}\text { Papua New } \\
\text { Guinea }\end{array}$ & F. Benzoni & & LK022396 & LK022376 \\
\hline $\begin{array}{l}\text { UNIMIB } \\
\text { PFB056 }\end{array}$ & $\begin{array}{l}\text { Parascolymia } \\
\text { vitiensis }\end{array}$ & I & $\begin{array}{l}\text { Papua New } \\
\text { Guinea }\end{array}$ & F. Benzoni & LK022357 & & LK022377 \\
\hline $\begin{array}{l}\text { UNIMIB } \\
\text { PFB057 }\end{array}$ & $\begin{array}{l}\text { Parascolymia } \\
\text { vitiensis }\end{array}$ & I & $\begin{array}{l}\text { Papua New } \\
\text { Guinea }\end{array}$ & F. Benzoni & HF954204 & LK022397 & HF954291 \\
\hline $\begin{array}{l}\text { UNIMIB } \\
\text { PFB151 }\end{array}$ & $\begin{array}{l}\text { Parascolymia } \\
\text { vitiensis }\end{array}$ & I & $\begin{array}{l}\text { Papua New } \\
\text { Guinea }\end{array}$ & F. Benzoni & LK022358 & LK022398 & LK022378 \\
\hline
\end{tabular}




\begin{tabular}{|c|c|c|c|c|c|c|}
\hline $\begin{array}{l}\text { UNIMIB } \\
\text { PFB152 }\end{array}$ & $\begin{array}{l}\text { Parascolymia } \\
\text { vitiensis }\end{array}$ & I & $\begin{array}{l}\text { Papua New } \\
\text { Guinea }\end{array}$ & F. Benzoni & LK022399 & LK022379 \\
\hline $\begin{array}{l}\text { UNIMIB } \\
\text { BA117 }\end{array}$ & $\begin{array}{l}\text { Micromussa } \\
\text { amakusensis }\end{array}$ & $\mathrm{A}$ & $\begin{array}{l}\text { Gulf of } \\
\text { Aden }\end{array}$ & F. Benzoni & LK022400 & \\
\hline $\begin{array}{l}\text { UNIMIB } \\
\text { MU215 }\end{array}$ & $\begin{array}{l}\text { Micromussa } \\
\text { amakusensis }\end{array}$ & A & $\begin{array}{l}\text { Gulf of } \\
\text { Aden }\end{array}$ & F. Benzoni & LK022401 & \\
\hline $\begin{array}{l}\text { RMNH } \\
\text { coel } 40070\end{array}$ & $\begin{array}{l}\text { Phymastrea } \\
\text { multipunctata }\end{array}$ & A & $\begin{array}{l}\text { Sabah, } \\
\text { Malaysia }\end{array}$ & $\begin{array}{l}\text { B.W. } \\
\text { Hoeksema }\end{array}$ & LK022402 & \\
\hline $\begin{array}{l}\text { IRD } \\
\text { HS3169 }\end{array}$ & $\begin{array}{l}\text { Acanthastrea } \\
\text { hillae }\end{array}$ & $\mathrm{B}$ & $\begin{array}{l}\text { New } \\
\text { Caledonia }\end{array}$ & F. Benzoni & LK022403 & \\
\hline $\begin{array}{l}\text { IRD } \\
\text { HS3225 }\end{array}$ & $\begin{array}{l}\text { Acanthastrea } \\
\text { hillae }\end{array}$ & $\mathrm{B}$ & $\begin{array}{l}\text { New } \\
\text { Caledonia }\end{array}$ & F. Benzoni & LK022404 & \\
\hline $\begin{array}{l}\text { IRD } \\
\text { HS3298 }\end{array}$ & $\begin{array}{l}\text { Acanthastrea } \\
\text { bowerbanki }\end{array}$ & $\mathrm{B}$ & $\begin{array}{l}\text { New } \\
\text { Caledonia }\end{array}$ & F. Benzoni & LK022405 & \\
\hline $\begin{array}{l}\text { UNIMIB } \\
\text { BA136 }\end{array}$ & $\begin{array}{l}\text { Acanthastrea } \\
\text { maxima }\end{array}$ & $\mathrm{C}$ & $\begin{array}{l}\text { Gulf of } \\
\text { Aden }\end{array}$ & F. Benzoni & LK022406 & \\
\hline $\begin{array}{l}\text { UNIMIB } \\
\text { MU161 }\end{array}$ & $\begin{array}{l}\text { Acanthastrea } \\
\text { maxima }\end{array}$ & $\mathrm{C}$ & $\begin{array}{l}\text { Gulf of } \\
\text { Aden }\end{array}$ & F. Benzoni & LK022407 & \\
\hline $\begin{array}{l}\text { UNIMIB } \\
\text { DJ288 }\end{array}$ & $\begin{array}{l}\text { Acanthastrea } \\
\text { echinata }\end{array}$ & $\mathrm{E}$ & Djibouti & F. Benzoni & LK022408 & \\
\hline $\begin{array}{l}\text { IRD } \\
\text { HS3228 }\end{array}$ & $\begin{array}{l}\text { Acanthastrea } \\
\text { subechinata }\end{array}$ & $\mathrm{E}$ & $\begin{array}{l}\text { New } \\
\text { Caledonia }\end{array}$ & F. Benzoni & LK022409 & \\
\hline $\begin{array}{l}\text { UNIMIB } \\
\text { PFB259 }\end{array}$ & $\begin{array}{l}\text { Acanthastrea } \\
\text { rotundoflora }\end{array}$ & $E$ & $\begin{array}{l}\text { Papua New } \\
\text { Guinea }\end{array}$ & F. Benzoni & LK022410 & \\
\hline $\begin{array}{l}\text { IRD } \\
\text { HS3065 }\end{array}$ & $\begin{array}{l}\text { Acanthastrea } \\
\text { hemprichii }\end{array}$ & $\mathrm{E}$ & $\begin{array}{l}\text { New } \\
\text { Caledonia }\end{array}$ & F. Benzoni & LK022411 & \\
\hline $\begin{array}{l}\text { UNIMIB } \\
\text { BA001 }\end{array}$ & $\begin{array}{l}\text { Echinophyllia } \\
\text { aspera }\end{array}$ & $\mathrm{F}$ & $\begin{array}{l}\text { Gulf of } \\
\text { Aden }\end{array}$ & F. Benzoni & LK022412 & \\
\hline $\begin{array}{l}\text { UNIMIB } \\
\text { PFB189 }\end{array}$ & $\begin{array}{l}\text { Echinophyllia } \\
\text { echinoporoides }\end{array}$ & $\mathrm{F}$ & $\begin{array}{l}\text { Papua New } \\
\text { Guinea }\end{array}$ & F. Benzoni & LK022413 & \\
\hline $\begin{array}{l}\text { IRD } \\
\text { HS3248 }\end{array}$ & $\begin{array}{l}\text { Echinophyllia } \\
\text { orpheensis }\end{array}$ & $\mathrm{F}$ & $\begin{array}{l}\text { New } \\
\text { Caledonia }\end{array}$ & F. Benzoni & LK022414 & \\
\hline $\begin{array}{l}\text { IRD } \\
\text { HS3171 }\end{array}$ & $\begin{array}{l}\text { Echinophyllia } \\
\text { echinata }\end{array}$ & G & $\begin{array}{l}\text { New } \\
\text { Caledonia }\end{array}$ & F. Benzoni & LK022415 & \\
\hline $\begin{array}{l}\text { IRD } \\
\text { HS3172 }\end{array}$ & Oxypora lacera & G & $\begin{array}{l}\text { New } \\
\text { Caledonia }\end{array}$ & F. Benzoni & LK022416 & \\
\hline $\begin{array}{l}\text { IRD } \\
\text { HS3203 }\end{array}$ & Oxypora lacera & G & $\begin{array}{l}\text { New } \\
\text { Caledonia }\end{array}$ & F. Benzoni & LK022417 & \\
\hline $\begin{array}{l}\text { UNIMIB } \\
\text { MY011 }\end{array}$ & $\begin{array}{l}\text { Cynarina } \\
\text { lacrymalis }\end{array}$ & $\mathrm{H}$ & Mayotte & F. Benzoni & LK022418 & \\
\hline $\begin{array}{l}\text { IRD } \\
\text { HS1604 }\end{array}$ & $\begin{array}{l}\text { Cynarina } \\
\text { lacrymalis }\end{array}$ & $\mathrm{H}$ & $\begin{array}{l}\text { New } \\
\text { Caledonia }\end{array}$ & F. Benzoni & LK022419 & \\
\hline $\begin{array}{l}\text { UNIMIB } \\
\text { AD003 }\end{array}$ & $\begin{array}{l}\text { Lobophyllia } \\
\text { corymbosa }\end{array}$ & I & $\begin{array}{l}\text { Gulf of } \\
\text { Aden }\end{array}$ & F. Benzoni & LK022420 & \\
\hline $\begin{array}{l}\text { UNIMIB } \\
\text { GA024 }\end{array}$ & $\begin{array}{l}\text { Lobophyllia } \\
\text { costata }\end{array}$ & I & Gambier & F. Benzoni & LK022421 & \\
\hline $\begin{array}{l}\text { UNIMIB } \\
\text { BA134 }\end{array}$ & $\begin{array}{l}\text { Lobophyllia } \\
\text { hemprichii }\end{array}$ & $\mathrm{I}$ & $\begin{array}{l}\text { Gulf of } \\
\text { Aden }\end{array}$ & F. Benzoni & LK022422 & \\
\hline $\begin{array}{l}\text { UNIMIB } \\
\text { PFB183 }\end{array}$ & $\begin{array}{l}\text { Lobophyllia } \\
\text { robusta }\end{array}$ & I & $\begin{array}{l}\text { Papua New } \\
\text { Guinea }\end{array}$ & F. Benzoni & LK022423 & \\
\hline UNIMIB & Symphyllia & I & Papua New & F. Benzoni & LK022424 & \\
\hline
\end{tabular}




\begin{tabular}{|l|l|l|l|l|l|l|l|}
\hline PFB104 & agaricia & & Guinea & & & \\
\hline $\begin{array}{l}\text { UNIMIB } \\
\text { BA107 }\end{array}$ & $\begin{array}{l}\text { Symphyllia } \\
\text { radians }\end{array}$ & I & $\begin{array}{l}\text { Gulf of } \\
\text { Aden }\end{array}$ & F. Benzoni & & LK022425 & \\
\hline $\begin{array}{l}\text { IRD } \\
\text { HS3118 }\end{array}$ & Symphyllia recta & I & $\begin{array}{l}\text { New } \\
\text { Caledonia }\end{array}$ & F. Benzoni & & LK022426 & \\
\hline $\begin{array}{l}\text { IRD } \\
\text { HS3135 }\end{array}$ & $\begin{array}{l}\text { Symphyllia } \\
\text { valenciennesii }\end{array}$ & I & $\begin{array}{l}\text { New } \\
\text { Caledonia }\end{array}$ & F. Benzoni & & LK022427 & \\
\hline
\end{tabular}




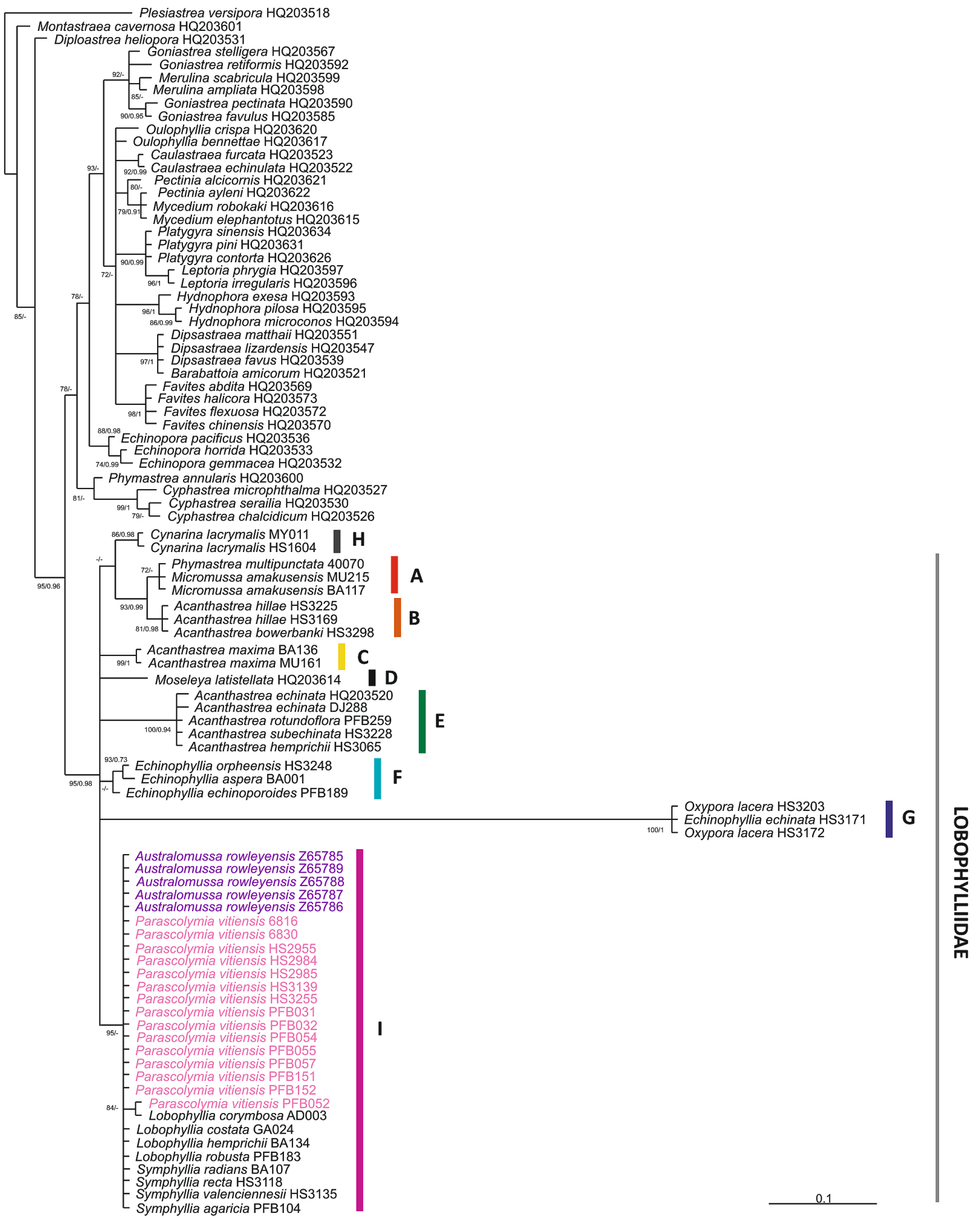




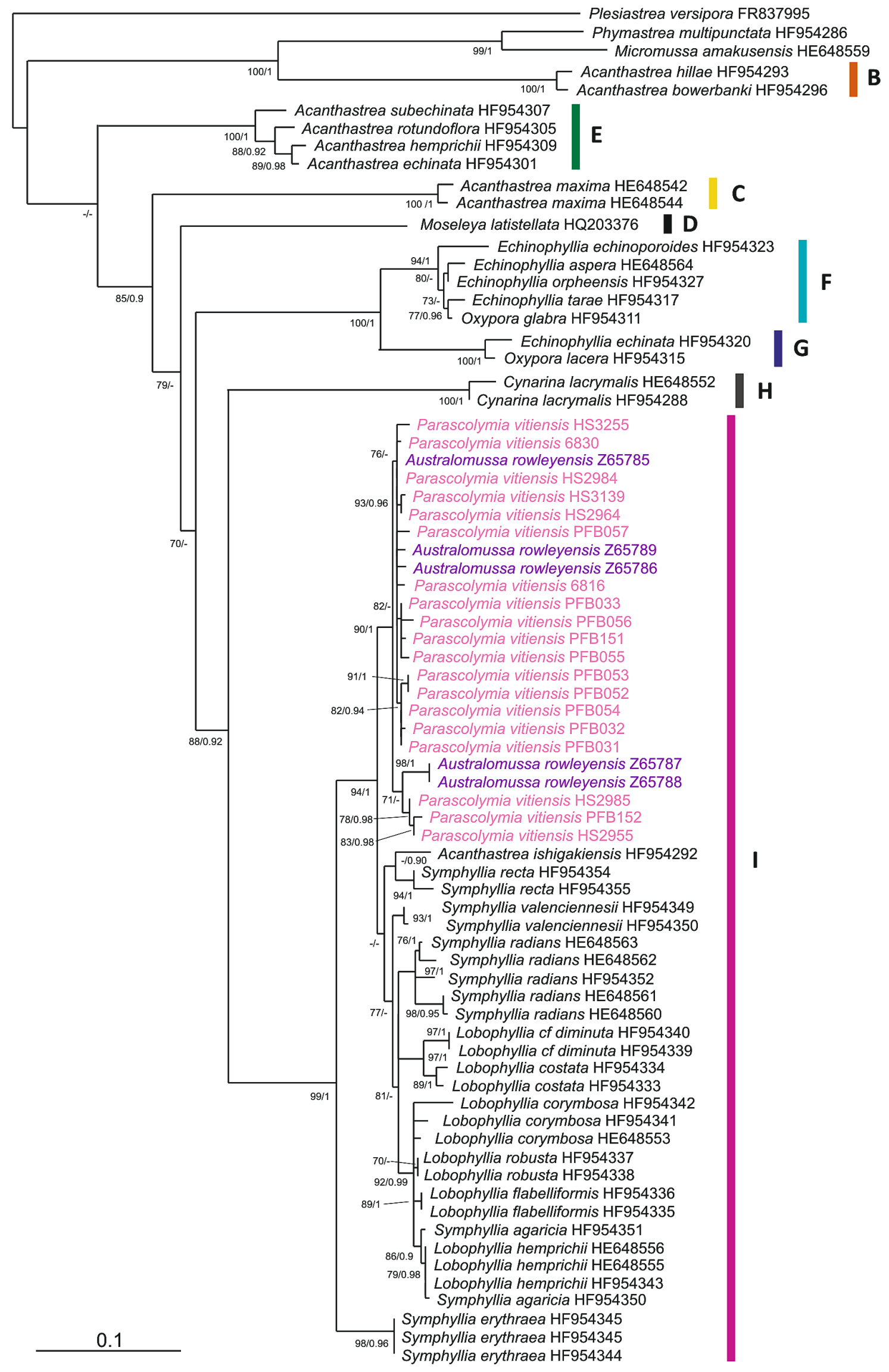



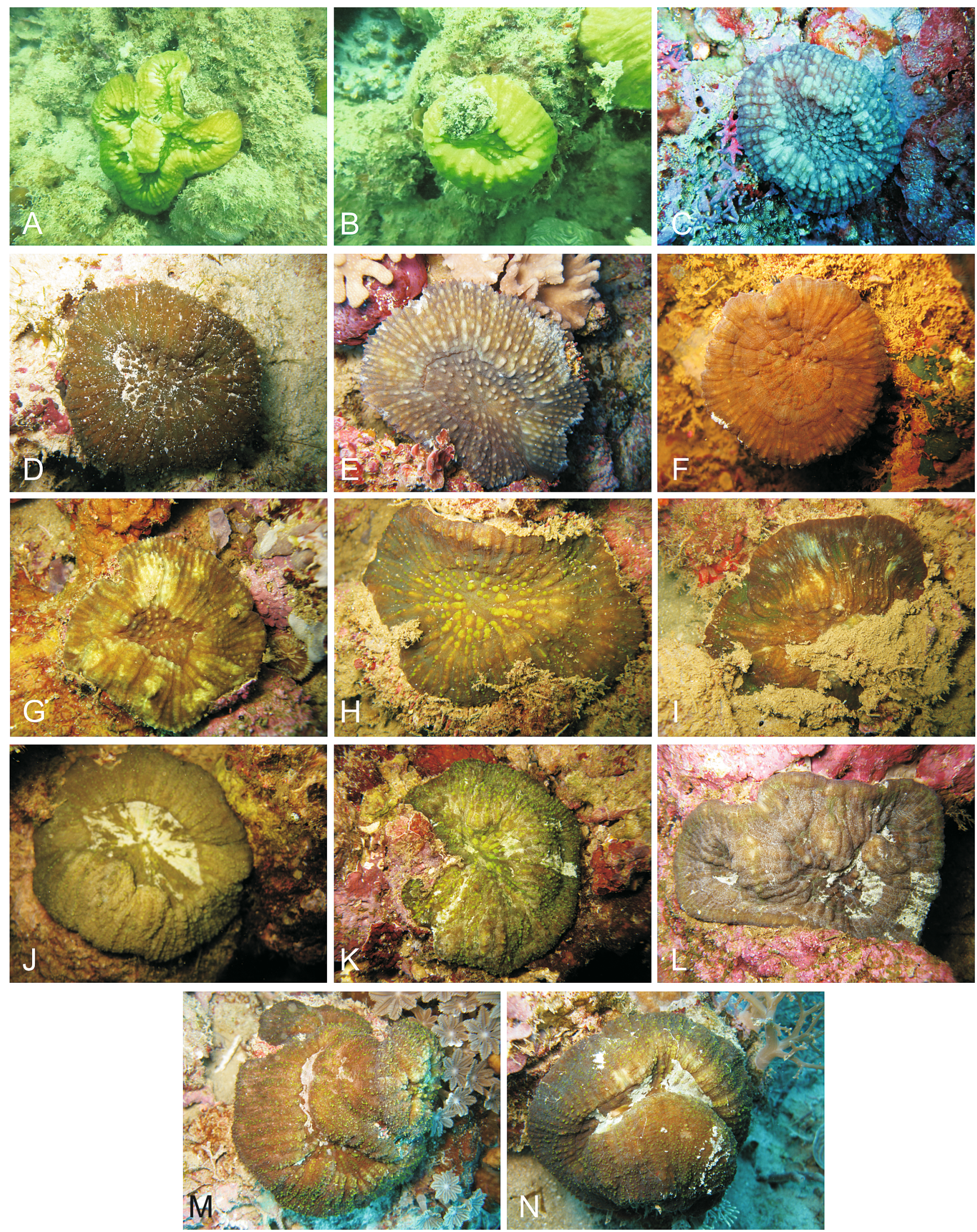